\title{
増令的にみた臨床的歯冠形態に関する研究
}

\author{
松本直之 \\ 東京医科歯科大学補緅学教室（指導 林都志夫教授）
}

(昭和 39 年 10 月 15 日受付)

\section{A Chronological Study on the Form of Clinical Tooth Crown}

Nahoyuki Matsumoto

\begin{abstract}
Dept. of prosthetic Dentistry, School of Dentistry, Tokyo Medical and Dental University
\end{abstract}
(Director: Prof. T. Hayashi)

\section{I 緒 言}

義歯に自然観を与えるため，われわれは，まず 前歯部人工歯の形および色調について適正な選択 を行なわねばならない。特に, 前者については Williams $^{1)}$ の 3 基本型をはじめとして，いろいろ の角度から検討された型見本があつて，それぞれ 指定の方法によれば，ほぼ適正な選択が行なわれ るようになつてはいる党。しかし，最終的な義歯 の自然観は解剖的な前歯部，特に，歯肉縁におけ る形態を修正して，どのような臨床的歯冠形態を 与えるかによつて大きく左右され，これにより義 歯の性, 年㱓, 性格等が与えられる。

したがつて, 最近これらの事項に関する研究が かなり活発に行なわれているが，適切な計測に よる数量的な取扱いを行なつたものはほとんどな い。そこで, 著者は臨床的歯冠形態の数量的表現 を目的として,まず, 解剖的歯冠形態を調査し計測 值による歯型の分類を行なつたのち, 臨床的に健 康と思われる歯肉縁形態を有する歯牙の形態すな わち臨床的歯冠形態を調查し, その年齢, 性別, 歯種との関係を検討したところ, 興味ある結果が 得られたのでここに報告する。

\section{II 研究方法および資料}

本研究は前述のとおり，抜去歯牙を資料とする 解剖的歯冠形態に関する研究と被験者から採取し
た正常歯列模型を資料とする臨床的歯冠形態に関 する研究とよりなる。抜去歯牙は1 1219 歯， 2 は 277 歯，追は 236 歯で, 計 732 歯を資料とし, 正常歯列模型は ô 973 歯, ○ 1093 歯, 計 2,066 歯を対象とした。

研究方法は観察と計測とによつたが, 特に, 計測 は, 主として1歯ごとに撮影した規格写真上で行 なつた。規格写真の撮影には飛奈 ${ }^{4)}$ の規格写真撮 影装置を使用したが，抜去歯牙については標本を 直接撮影し，模型歯については歯列模型を複印象 して副模型を製作し，これから 1 歯ごとの分割模 型を得て、これを撮影した。

\section{規格写真撮影装置ならびに撮影方法}

規格写真は歯冠の唇面観を 撮影して得られた が，その基準平面は富士川 ${ }^{5)}$ の歯冠軸決定方法に 従つた。すなわち(図 1)

1. 近遠心方向より見た歯冠軸(A)

唇舌歯頸間の中点と切縁を結ぶ直線

2. 唇舌方向から見た歯冠軸(B)

唇側歯頸および最大幅径部の中点を結ぶ直線

3. 近遠心的基準平面 (C)

歯冠を唇側と舌側とに 2 分し，近遠心方向を 表わす平面。切縁を通り歯冠軸を含む平面。 として, 写真 1 に示すような歯冠軸決定装置上の 金属体に分割模型(写真 2 )を据え, それぞれの基 準平面を決定したのちワックスで固定し，これを 


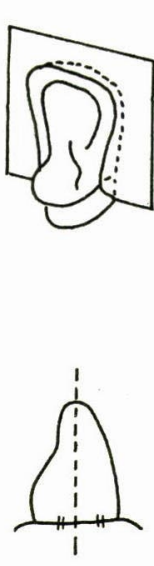

A
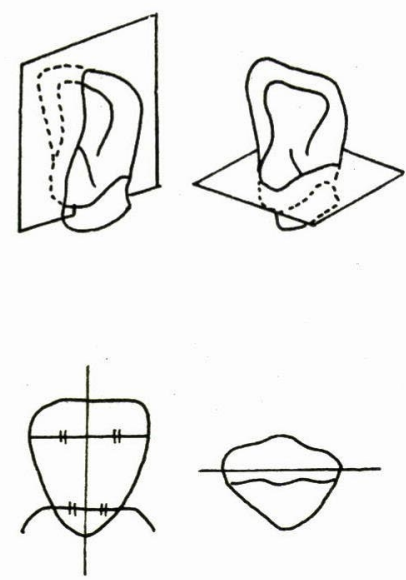

B

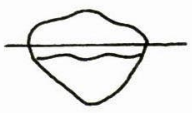

C
図 1 歯冠軸決定方法
A： 近遠心的基準平面（近遠心方向から見た 歯冠軸の基準)
B：唇舌的基準平面（唇舌方向から見た歯冠 軸の基準)
$\mathrm{C}$ ：水平基準平面（歯冠の近遠心方向の基準）

撮影の対象とした。この金属体は正確な立方形を なす金属体であつて, 撮影に際し, 一定の方向と 位置とを確保することができる。

次に, 写真撮影装置は写真 1 に示すように写真 機固定台 $(\mathrm{A})$ と被写体固定装置 (B) とからなつて いる。Bの中央には, 昇降装置によつて下方から 運ばれた被写体を正しく基準面に一致させるため に方形の空があいており，そのまわりに $1 / 2 \mathrm{~mm}$ 目盛の刻みがある。 $\mathrm{A}$ 亿・ $135 \mathrm{~mm}$ のレンズお よび $80 \mathrm{~mm}$ の中間リングを使用すれば，スケー ル板面に一致した被写体の映像は実物の 0.7 倍に なるように調節されている。この装置を用いて撮 影した写真を，さらに，実物の 4 倍になるように 引き伸ばし計測の対象とした(写真 3 )。

\section{計測部位および方法}

写真上で唇面歯冠軸を決定したのち, 次の各項 について計測を行なつた(図 2)。

1. 歯冠最大幅径 (B)

歯冠軸に直角な歯冠の最大幅

2. 歯冠の最大長 $(\mathrm{L})$

歯冠軸に平行な歯冠の最大長

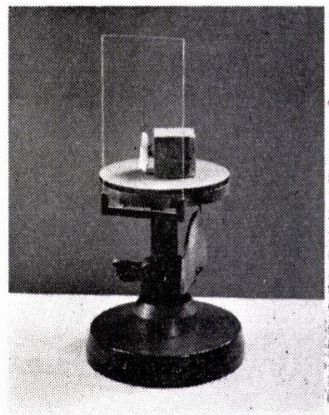

1

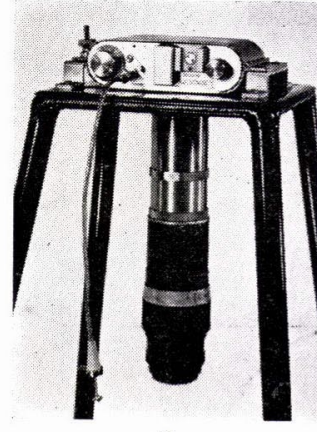

3

写真 1 歯冠軸決定装置 (1) と規格写真撮影 装置 $(2 ， 3 ， 4)$

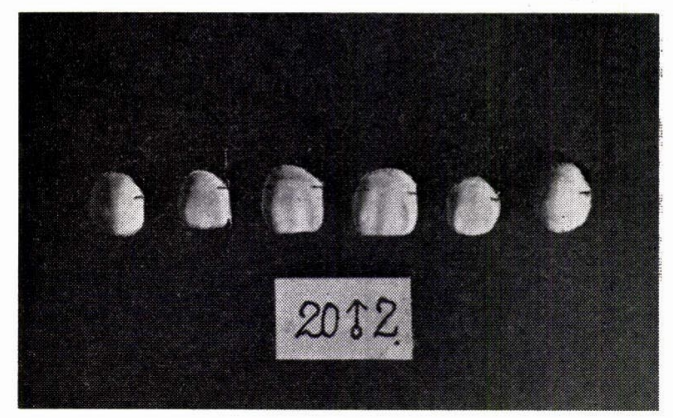

写真 2 分 割 模 型

なお, 臨床歯冠の計測に加えて, 歯間乳頭の位置 および歯肉縁の形状について計測したが，これに ついては臨床歯冠形態の項でくわしく説明する。

\section{咬耗の補正}

歯牙の咬耗は多かれ少なかれ全歯牙に認められ るが，計測資料はできるだけ咬耗の少ないものを 選んだ。しかし実際には, 計測にあたつて咬耗を補 正しなければならないものがかなりあつた。この 場合の補正は菖蒲沢 ${ }^{6)}$ のエナメル質の厚さ，なら びに咬耗に関する報告 ${ }^{718)}$ を)参考として, 歯冠の 


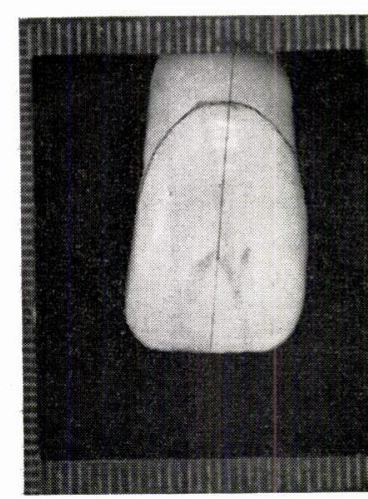

1

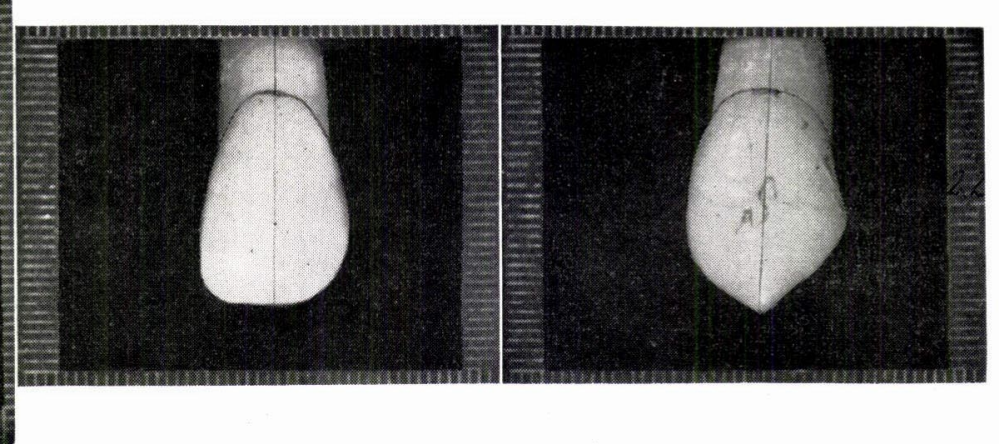

$\underline{2}$

3

写真 3 規格写真

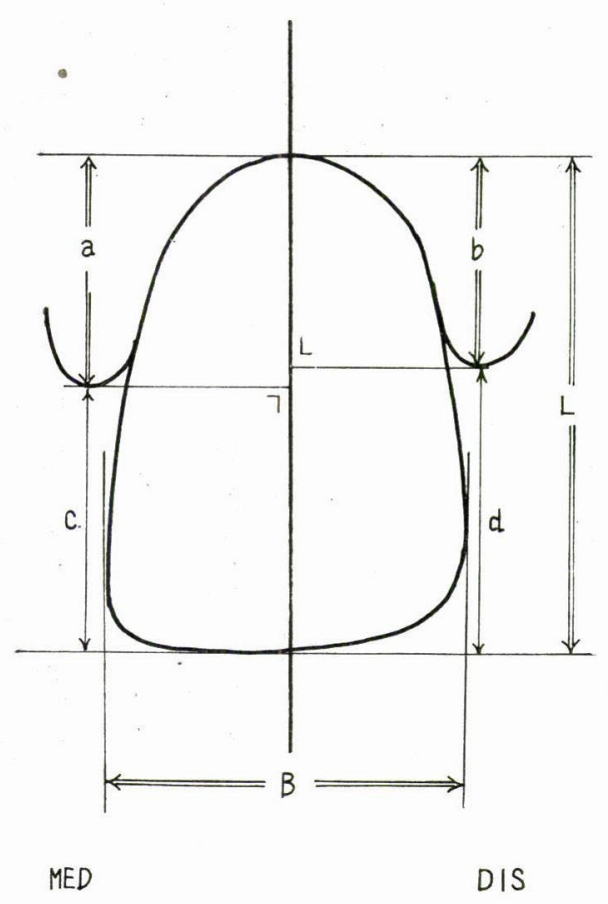

図 2 計 測 部 位

概形から歯冠形態を回復する方法を採つた。

\section{III 研 究 結 果}

1. 抜去歯牙による解剖的歯冠形態について 抜去歯牙を対象として歯冠の最大幅および最大 長を求め, これから歯冠の幅長示数を算出した結 果, 表 1 が得られた。しかし, これらの值は1,
는 $\underline{3}$ とに正規型分布をなしてはいるが，その分 散がはなはだ大きく，例数は多いが不揃いな材料 から統計したものであることが予想された。そこ で, 試みにこれらを正規母集団よりの無作為標本 と仮定して危険率 1\%拉よび $5 \%$ で

$$
\overline{\mathrm{x}}+\mu \sqrt{\frac{\mathrm{N}+1}{\mathrm{~N}} \mathrm{~F}_{0}} \geqq \mathrm{x}_{0} \geqq \overline{\mathrm{x}}-\mu \sqrt{\frac{\mathrm{N}+1}{\mathrm{~N}} \mathrm{~F}_{0}}
$$

の式を用いて幅長示数の衰却限界を求めたところ 限界外にあるものは各歯種につき $11 \sim 15$ 例の多 きにのぼり, 標本そのものの母集団の純度を疑わ せるものがあつた。そこで, 著者は単なる幅長示 数の分散による資料の分類を避けて, 歯冠長, 歯冠 幅それぞれの平均值の確率誤差 $\mathrm{PE} \sigma_{\mathrm{x}}, \mathrm{PE} \sigma_{\mathrm{y}}(\overline{\mathrm{x}}$, $\overline{\mathrm{y}}, \sigma_{\mathrm{x}}, \sigma_{\mathrm{y}}$ はそれぞれ歯冠幅, 歯冠長の平均值拧 よび標準誤差）による標本の分類を行なうことに した。図 3，4，5 はその際用いた各歯種別の計算 図表（Z図表）である。すなわち，X軸に歯冠幅 を，Y軸に歯冠長を採り，それぞれの度数分布 をとストグラフとして描き，そこに平均值，確率 䛊差值を表示すると, $Z$ 軸は 歯冠幅長示数 $Z=$ $\frac{\mathrm{Y}}{\mathrm{X}} \times 100$ を表わしていることになる。この図上 で, 歯冠幅, 歯冠長の平均值の確率誤差の上限お よび下限を結べば, 歯冠幅長示数の最大值と最小 值の存在範囲が求められる。つまり, この範囲内 にあるものが幅長示数の正常型 $(\mathrm{N}$ 型)としてみな されることになる。そして，この範囲よりも大き な示数を持つものは長型 $(\mathrm{L}$ 型) の歯冠であり, 小 
表 1 抜去歯牙 : 幅長示数の推計表（\%は充却限界の危険率を示す）

\begin{tabular}{|c|c|c|c|}
\hline & 1 & $\underline{2}$ & $\underline{3}$ \\
\hline $\mathrm{N}$ & 219 & 277 & 236 \\
\hline$\overline{\mathrm{x}}$ & 141.33 & 145.50 & 144.79 \\
\hline$u^{2}$ & 75.25 & 116.86 & 154.65 \\
\hline $1 \%$ & $163.93 \geqq \mathrm{X}_{0} \geqq 118.73$ & $173.65 \geqq \mathrm{X}_{0} \geqq 117.34$ & $177.19 \geqq \mathrm{X}_{0} \geqq 112.39$ \\
\hline $5 \%$ & $158.47 \geqq \mathrm{X}_{0} \geqq 124.19$ & $166.85 \geqq \mathrm{X}_{0} \geqq 124.14$ & $169.36 \geqq \mathrm{X}_{0} \geqq 120.21$ \\
\hline $\begin{array}{l}1 \% \text { 限界より大 } \\
\text { 限界より小 }\end{array}$ & $\begin{array}{l}4 \\
1\end{array}$ 例 & $\begin{array}{l}0 \\
1\end{array}$ 例 & $\begin{array}{l}1 \\
0\end{array}$ 例 \\
\hline $\begin{array}{l}5 \% \text { 限界より大 } \\
\text { 限界より小 }\end{array}$ & $\begin{array}{l}8 \\
5\end{array}$ 例 & $\begin{array}{l}6 \\
5\end{array}$ 例 & $\begin{array}{r}14 \\
1\end{array}$ 例 \\
\hline
\end{tabular}

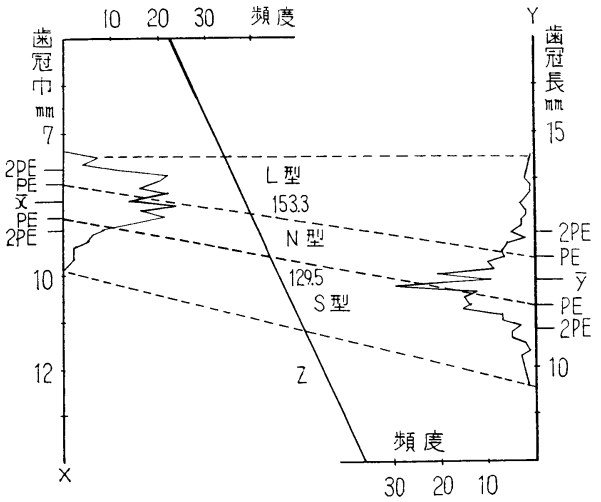

1

図 3 抜去歯牙 : 解剖的歯冠形態の分類図表

$$
\begin{aligned}
\overline{\mathrm{x}} & =8.39 & \overline{\mathrm{y}} & =11.84 \\
\overline{\mathrm{x}}+\mathrm{PE} & =8.71 & \overline{\mathrm{y}}+\mathrm{PE} & =12.36 \\
\overline{\mathrm{x}}-\mathrm{PE} & =8.07 & \overline{\mathrm{y}}-\mathrm{PE} & =11.32
\end{aligned}
$$

さな示数を持つものは短型 $(\mathrm{S}$ 型)の歯冠とみなさ れる(図 6 )。

このほかに歯冠幅, 歯冠長で, それぞれの $\pm \mathrm{PE} \sigma$ の範囲内にないが，示数のうえからは正常型にあ る場合がある。このような移行型については各歯 冠幅，歯冠長の $\pm \mathrm{PE} \sigma \sim \pm 2 \mathrm{PE} \sigma$ 内に分布するも ののみをとり, 改めて, 歯冠の形態を肉眼的に観 察を加え, 長型, 正常型, 短型のいずれかの類型 中に含めた。

上記分類方法で各歯種別に分類したところ, 正 常型が 60 \%前後を示し, 長型, 短型とも $20 \%$ 前 後となつた。さらに 1 ， 2 においては長型が短型 よりわずかに多く，正においては反詨に短型が多 かつた。また，正常型を相似的に大きくしたもの

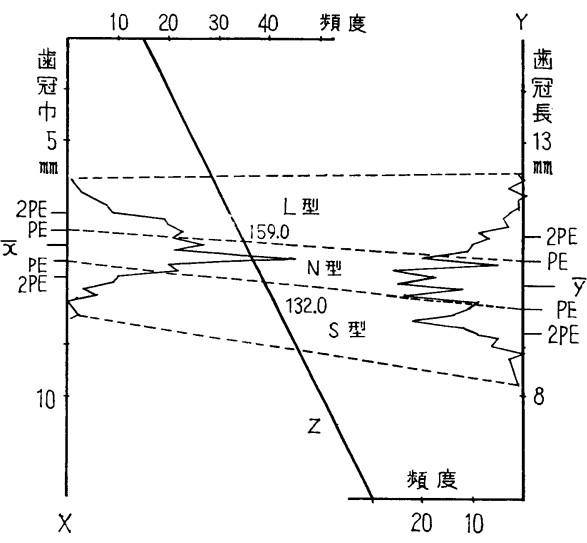

$\underline{2}$

図 4 抜去歯牙: 解剖的歯冠形態の分類図表

$$
\begin{aligned}
\overline{\mathrm{x}} & =7.04 & \overline{\mathrm{y}} & =10.21 \\
\overline{\mathrm{x}}+\mathrm{PE} & =7.36 & \overline{\mathrm{y}}+\mathrm{PE} & =10.69 \\
\overline{\mathrm{x}}-\mathrm{PE} & =6.72 & \overline{\mathrm{y}}-\mathrm{PE} & =9.73
\end{aligned}
$$

(Large N)，相似的に小さくしたもの (Small N) が数パーセントあつた。これらは正常型はもち ろん, 長型, 短型とも区別して拡大型または縮小 型として扱つた。

\section{ベクトル歯型}

上記の分類方法で分類された各歯牙は, その形 態要素をベクトルで表示することにより, 各分類 群間の形態的相互関係がさらに明確に図示される （図 7 ）。すなわち, 直角座標上の X軸に $\mathrm{a}_{1}$ ベク トル, $\mathrm{Y}$ 軸に $\mathrm{a}_{2}$ ベクトルを採ると、その複合ベク

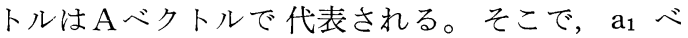
クトル， $\mathrm{a}_{2}$ ベクトルにそれぞれ歯冠長，歯冠幅 を代入すると，Aベクトルは各歯牙固有のものと 


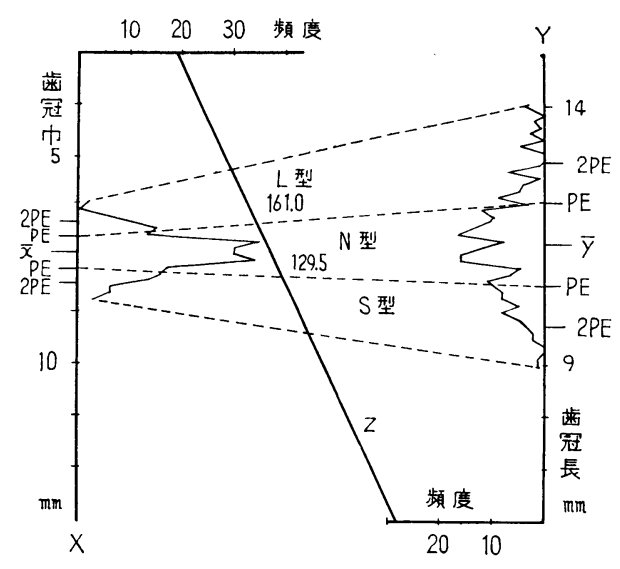

$\underline{3}$

図 5 抜去歯牙: 解剖的歯冠形態の分類図表

$$
\begin{aligned}
& \overline{\mathrm{x}}=7.85 \\
& \overline{\mathrm{x}}+\mathrm{PE}=8.14 \\
& \bar{y}=11.35 \\
& \overline{\mathrm{y}}+\mathrm{PE}=12.16 \\
& \overline{\mathrm{x}}-\mathrm{PE}=7.55 \\
& \overline{\mathrm{y}}-\mathrm{PE}=10.55
\end{aligned}
$$

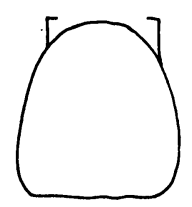

$S$ 型

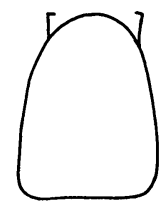

$N$ 型

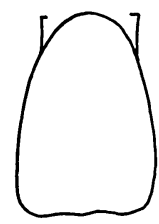

\begin{tabular}{|c|c|c|c|}
\hline & $\underline{1}$ & $\underline{2}$ & $\underline{3}$ \\
\hline 正 常 型 & $141(64.4)$ & $157(56.7)$ & $147(62.3)$ \\
\hline 長 型 & $35(16.0)$ & $63(22.7)$ & $35(14.8)$ \\
\hline 短 型 & $27(12.3)$ & $46(16.6)$ & $43(18.2)$ \\
\hline 拡 大 型 & $8(3.7)$ & $5(1.8)$ & $7(3.0)$ \\
\hline 縮 小型 & $8(3.7)$ & $6(2.2)$ & $4(1.7)$ \\
\hline 計 & 219 & 277 & 236 \\
\hline
\end{tabular}

$L$ 型
困 6 歯冠形態の 3 分類困

$\mathrm{S}$ 型: 短型 $\mathrm{N}$ 型 : 正常型 $\mathrm{L}$ 型 : 長型

表 2 抜去歯牙 : 歯冠形態分類表 （）は\%を示す

なり，各歯牙形態は原点より $\mathrm{A}$ 点までの距離と $\mathrm{X}$ 軸との角度で示されることになる。そして正常型 の歯牙群は，ある範囲のベクトル長さと角度を持 ち，長型，短型は正常型の範囲外に分散する。ま た, 先に述べた拡大, 縮小型は方向のみ正常型と

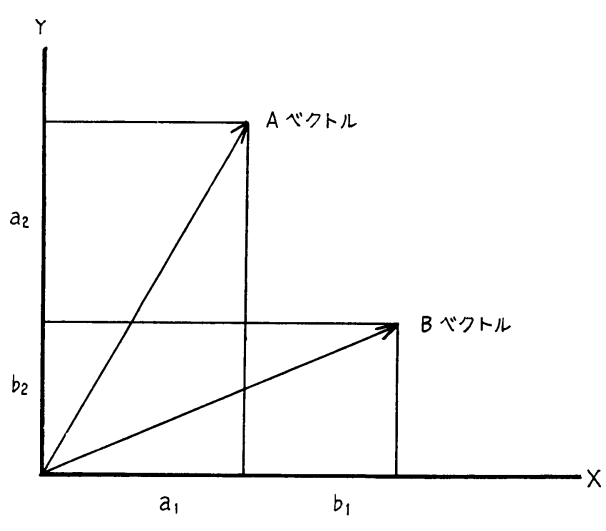

困 7 ベクトルの合成

同じであるが，長さについては全く正常型の存在 範囲からはみ出したものである。

\section{信頼㮁円面と棄却楕円面}

一変量を取り扱つた場合の正規母集団では母平 均の存在範囲を求めて, これを信頼限界と名ゔけ る。同様に, 一変量の棄却限界をもつて母集団の 存在範囲が示される。二変量の場合は複合ベクト ルとして，その信頼限界，棄却限界を求められ， ある危険率のもとで信頼棈円面，棄却楕円面とし て表わされる。その際, 次の計算式 ${ }^{10)}$ が用いられ る。

すなわち，N組の実験の一つ一つはそれぞれ測 定形式の同一な $\mathrm{k}$ 個の測定からなるとき

信頼楕円面

$$
\frac{(\mathrm{N}-\mathrm{k}) \mathrm{N}}{\mathrm{kF} \mathrm{F}_{0}} \sum_{\alpha=1}^{\mathrm{k}} \sum_{\beta=1}^{\mathrm{k}} \varphi_{\alpha \beta}\left(\overline{\mathrm{x}}_{\alpha}-\mathrm{m}_{\alpha}\right)\left(\overline{\mathrm{x}}_{\beta}-\mathrm{m}_{\beta}\right)=1
$$

棄却楕円面

$$
\begin{aligned}
& \frac{(\mathrm{N}-\mathrm{k}) \mathrm{N}}{\mathrm{k}(\mathrm{N}+1) \mathrm{F}(\mathrm{a})} \sum_{\alpha=1}^{\mathrm{k}} \sum_{\beta=1}^{\mathrm{k}} \varphi_{\alpha \beta}\left(\mathrm{x}_{0 \alpha}-\overline{\mathrm{x}}_{\alpha}\right)\left(\mathrm{x}_{0 \beta}-\overline{\mathrm{x}}_{\beta}\right)=1 \\
& \text { ただし } \\
& \overline{\mathrm{x}}: \text { 標本平均経過 } \\
& \mathrm{m}: \text { 母平均経過 } \\
& \mathrm{F}_{0}: \text { 自由度 } \mathrm{n}_{1}=\mathrm{k}, \mathrm{n}_{2}=\mathrm{N}-\mathrm{k} \text { に対するある } \\
& \quad \text { 信頼度の } \mathrm{F} \text { 表值 }
\end{aligned}
$$

$\mathrm{x}_{0}$ : $\mathrm{N}$ 組以外の新たな標本経過

$\mathrm{F}(\mathrm{a})$ ：自由度 $\mathrm{n}_{1}=\mathrm{k}, \mathrm{n}_{2}=\mathrm{N}-\mathrm{k}$ に対するあ る危険率の $\mathrm{F}$ 表値

以上の信頼楕円面および㙌却楕円面の公式を $\mathrm{k}$ $=2$ とする二次元に書き換えると， 
信頼楕円面

$$
\frac{(\mathrm{N}-2) \mathrm{N}}{2 \cdot \mathrm{F}_{0} \cdot \Delta}\left\{\phi_{22}\left(\overline{\mathrm{x}}_{1}-\mathrm{m}_{1}\right)^{2}-2 \phi_{12}\left(\overline{\mathrm{x}}_{1}-\mathrm{m}_{1}\right)\left(\overline{\mathrm{x}}_{2}-\mathrm{m}_{2}\right)+\phi_{11}\left(\overline{\mathrm{x}}_{2}-\mathrm{m}_{2}\right)^{2}\right\}=1
$$

\section{棄却楕円面}

$$
\frac{(\mathrm{N}-2) \mathrm{N}}{2(\mathrm{~N}+1) \cdot \mathrm{F}(\mathrm{a}) \cdot \Delta}\left\{\phi_{22}\left(\mathrm{x}_{01}-\overline{\mathrm{x}}_{1}\right)^{2}-2 \phi_{12}\left(\mathrm{x}_{01}-\overline{\mathrm{x}}_{1}\right)\left(\mathrm{x}_{02}-\overline{\mathrm{x}}_{2}\right)+\phi_{11}\left(\mathrm{x}_{02}-\overline{\mathrm{x}}_{2}\right)^{2}\right\}=1
$$

$$
\phi_{11}=\sum_{\mathrm{i}=1}^{\mathrm{N}}\left(\mathrm{x}_{\mathrm{i} 1}-\overline{\mathrm{x}}_{1}\right)^{2}
$$

$$
\phi_{21}=\phi_{12}=\sum_{\mathrm{i}=1}^{\mathrm{N}}\left(\mathrm{x}_{\mathrm{i} 1}-\overline{\mathrm{x}}_{1}\right)\left(\mathrm{x}_{\mathrm{i} 2}-\overline{\mathrm{x}}_{2}\right)
$$

$$
\begin{aligned}
& \phi_{22}=\sum_{\mathrm{i}=1}^{\mathrm{N}}\left(\mathrm{x}_{\mathrm{i} 2}-\overline{\mathrm{x}}_{2}\right)^{2} \\
& \Delta=\phi_{11} \phi_{22}-\phi_{12}{ }^{2}
\end{aligned}
$$

となる。この場合の 2 変量は歯冠長および歯冠幅 である。

さて，正常型抜去歯牙について，歯種別に 95 \%信頼棈円面および $5 \%$ 棄却楕円面を求めるとす れば表 3 が得られる。この公式から各楕円面を描 くには次の棈円の方程式を用いる。

$$
\begin{aligned}
& \alpha_{11}=\frac{(\mathrm{N}-\mathrm{k}) \cdot \mathrm{N} \cdot \phi_{22}}{\mathrm{k}(\mathrm{N}+1) \cdot \mathrm{F}(\mathrm{a}) \cdot \Delta} \\
& \left.\alpha_{12}=\frac{(\mathrm{N}-\mathrm{k}) \cdot \mathrm{N} \cdot \phi_{12}}{\mathrm{k}(\mathrm{N}+1) \cdot \mathrm{F}(\mathrm{a}) \cdot \Delta}-\Delta^{-}\right\} \text {とすると } \\
& \alpha_{22}=\frac{(\mathrm{N}-\mathrm{k}) \cdot \mathrm{N} \cdot \phi_{11}}{\mathrm{k}(\mathrm{N}+1) \cdot \mathrm{F}(\mathrm{a}) \cdot \Delta} \\
& \alpha_{11}\left(\mathrm{x}_{01}-\overline{\mathrm{x}}_{1}\right)^{2}+2 \alpha_{12}\left(\mathrm{x}_{01}-\overline{\mathrm{x}}_{1}\right)\left(\mathrm{x}_{02}-\overline{\mathrm{x}}_{2}\right) \\
& +\alpha_{22}\left(\mathrm{x}_{02}-\overline{\mathrm{x}}_{2}\right)^{2}=1
\end{aligned}
$$

棈円の中心 $\left(\vec{x}_{1}, \bar{x}_{2}\right)$ を原点に移すと

$$
\begin{gathered}
\alpha_{11} \xi_{1}^{2}+2 \alpha_{12} \xi_{1} \xi_{2}+\alpha_{22} \xi_{2}^{2}=1 \\
\tan 2 \theta=\frac{2 \alpha_{12}}{\alpha_{11}-\alpha_{22}}\left(\frac{\pi}{2}>\theta>0\right) \\
\lambda^{2}-\left(\alpha_{11}+\alpha_{22}\right) \lambda+\left(\alpha_{11} \alpha_{22}-\alpha^{2}{ }_{12}\right)=0 \\
\alpha_{12}<0 \text { なるとき } \quad \lambda_{1} \cdots \text { 小根 } \\
\lambda_{2} \cdots \text { 大根 } \\
\therefore \frac{\xi_{1}{ }^{2}}{\frac{1}{\lambda_{1}}}+\frac{\xi_{2}{ }^{2}}{\frac{1}{\lambda_{2}}}=1
\end{gathered}
$$

焦点距離 $\mathrm{C}^{2}=\frac{1}{\lambda_{1}}-\frac{1}{\lambda_{2}}$

上記の方法で抜去歯牙の正常型について $5 \%$ の 棄却楕円を求め表 4 に示した。

\section{ベクトル表示法による各歯型の分布状態}

抜去歯牙の歯冠幅, 歯冠長の分散より正常型, 短型, 長型の 3 型に分類し, それら 3 型のベクト ルによる位置的関係を図示しながら，正常型につ

表 3 抜去歯牙: 正常型の棈円面 (計測值による推計值)

\begin{tabular}{c|c}
\hline \hline & $95 \%$ 信 頼 棈 円 面 \\
\hline 1 & $\begin{array}{l}11.96\left(46.96-\mathrm{m}_{1}\right)^{2}-18.35\left(46.96-\mathrm{m}_{1}\right) \times \\
\left(33.45-\mathrm{m}_{2}\right)+20.46\left(33.45-\mathrm{m}_{2}\right)^{2}=1\end{array}$ \\
\hline$\underline{2}$ & $\begin{array}{l}8.39\left(40.78-\mathrm{m}_{1}\right)^{2}-4.85\left(40.78-\mathrm{m}_{1}\right) \times(28.25- \\
\left.\mathrm{m}_{2}\right)+18.29\left(28.25-\mathrm{m}_{2}\right)^{2}=1\end{array}$ \\
\hline$\underline{3}$ & $\begin{array}{l}5.94\left(45.178-\mathrm{m}_{1}\right)^{2}-12.19\left(45.17-\mathrm{m}_{1}\right) \times \\
\left(31.38-\mathrm{m}_{2}\right)+27.86\left(31.38-\mathrm{m}_{2}\right)^{2}=1\end{array}$ \\
\hline$\underline{1}$ & $\begin{array}{l}0.084\left(\mathrm{x}_{01}-46.957\right)^{2}-0.129\left(\mathrm{x}_{01}-46.957\right) \times \\
\left(\mathrm{x}_{02}-33.450\right)+0.144\left(\mathrm{x}_{02}-33.450\right)^{2}=1\end{array}$ \\
\hline$\underline{2}$ & $\begin{array}{l}0.053\left(\mathrm{x}_{01}-40.777\right)^{2}-0.031\left(\mathrm{x}_{01}-40.777\right) \times \\
\left(\mathrm{x}_{02}-28.245\right)+0.116\left(\mathrm{x}_{02}-28.245\right)^{2}=1\end{array}$ \\
\hline$\underline{3}$ & $\begin{array}{l}0.040\left(\mathrm{x}_{01}-45.173\right)^{2}-0.082\left(\mathrm{x}_{01}-45.173\right) \times \\
\left(\mathrm{x}_{02}-31.380\right)+0.188\left(\mathrm{x}_{02}-31.380\right)^{2}=1\end{array}$ \\
\hline
\end{tabular}

表 4 抜去歯牙 : 正常型の $5 \%$ 棄却棈円の各值 (計測值による推計值)

\begin{tabular}{c|c|c|c}
\hline \hline & $\underline{1}$ & $\underline{2}$ & $\underline{3}$ \\
\hline$\overline{\mathrm{x}}_{1}=$ 歯冠長 & 46.96 & 40.78 & 45.17 \\
$\overline{\mathrm{x}}_{2}=$ 歯冠幅 & 33.45 & 28.25 & 31.38 \\
$\alpha_{11}$ & 0.0842 & 0.0531 & 0.0401 \\
$\alpha_{12}$ & -0.0646 & -0.0153 & -0.0412 \\
$\alpha_{22}$ & 0.1441 & 0.1158 & 0.1882 \\
$\theta$ & $32^{\circ} 34^{\prime}$ & $13^{\circ} 3^{\prime}$ & $14^{\circ} 32^{\prime}$ \\
${ }^{\mathrm{E}}$ & 4.82 & 4.48 & 5.83 \\
長 径 & 4.82 & 2.24 \\
短 径 & 2.32 & 2.90 & 2.38 \\
焦点距離 & 4.23 & 3.41 & 5.38
\end{tabular}

いての $5 \%$ 棄却楕円を作図すると図 $8 ， 9 ， 10$ が 得られる。

中央の楕円は前項で計算された正常型について 


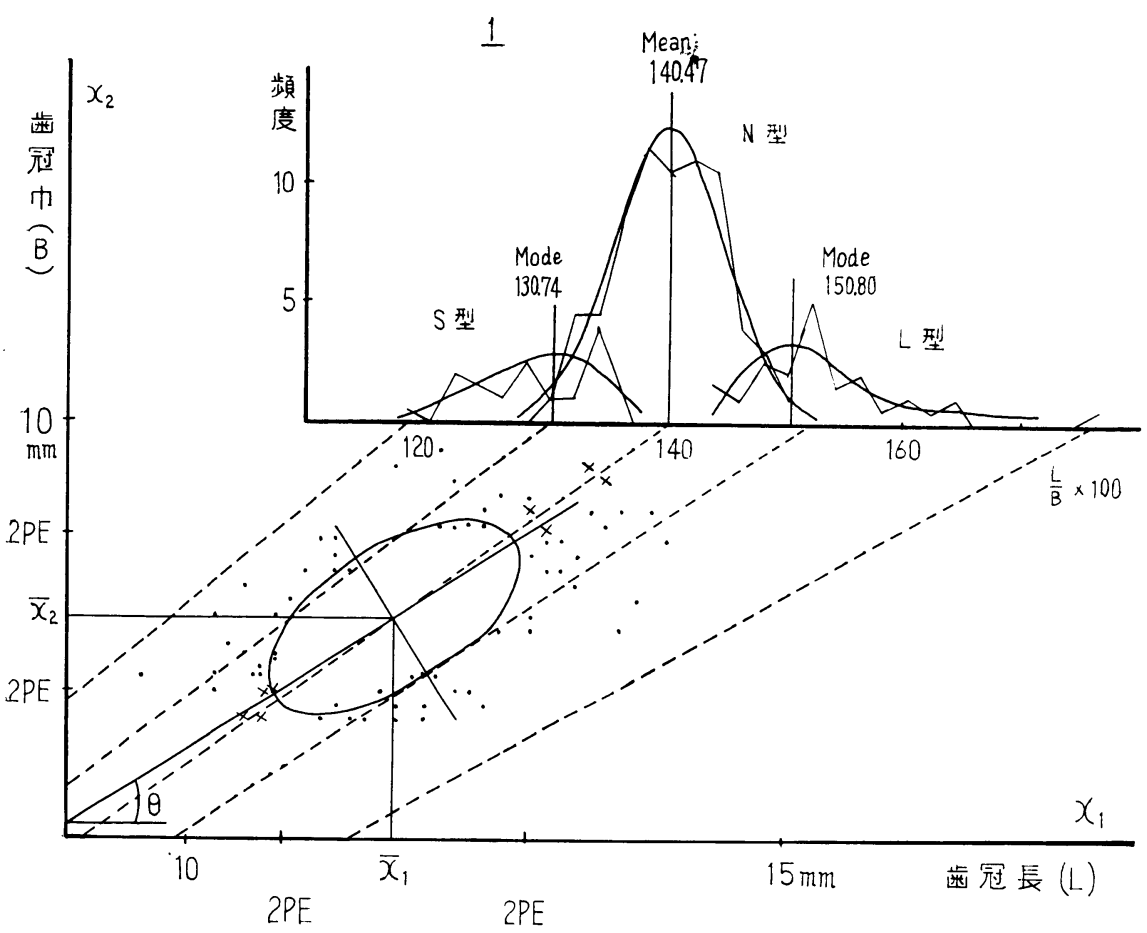

図 8 ベクトル表示法による各歯型の分布状態

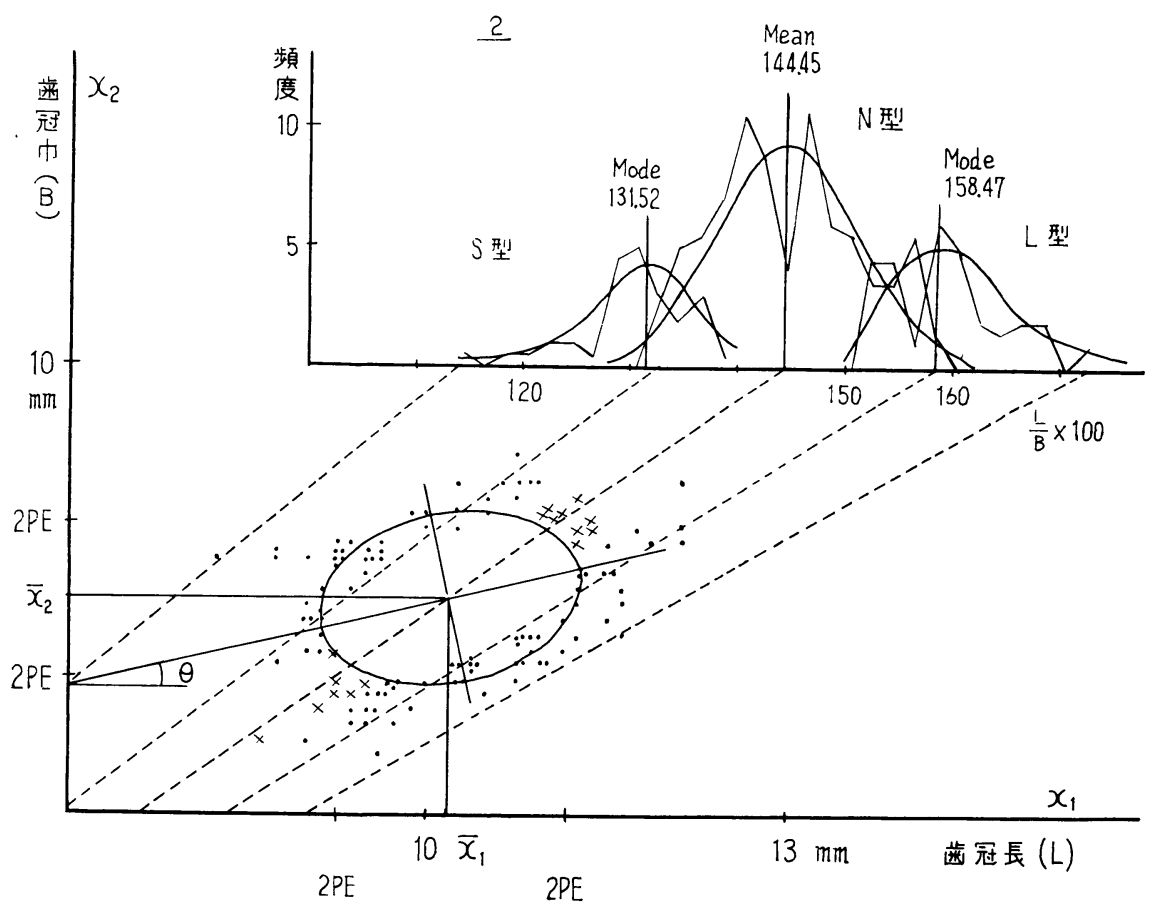

図 9 ベクトル表示法による各歯型の分布状態 


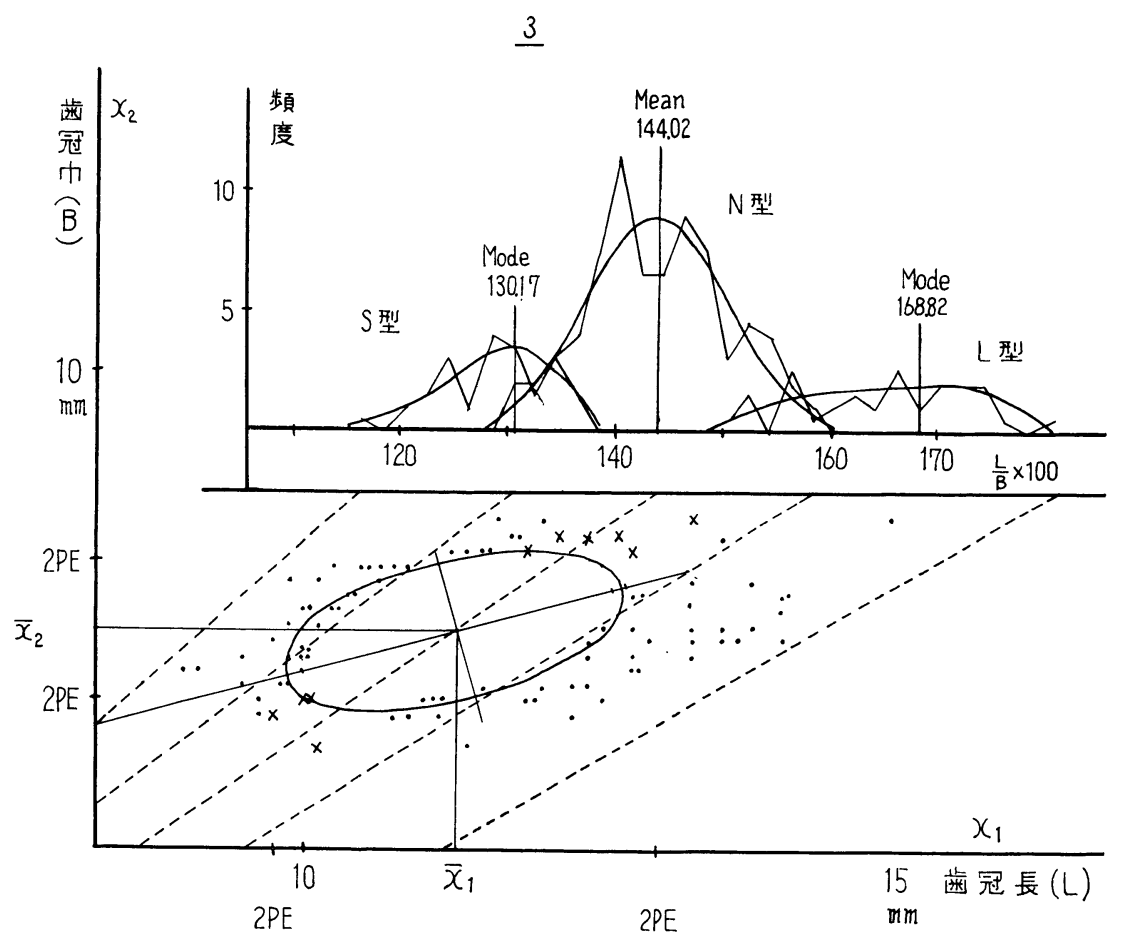

図 10 ベクトル表示法による各歯型の分布状態

の $5 \%$ 棄却楕円面であり，その棈円の中点は歯冠 幅, 歯冠長の各平均值を示す。また, 棈円の長軸と X軸とのなす角度 $\theta$ は 1 は $32^{\circ} 34^{\prime} ， 2$ は $13^{\circ} 3^{\prime}$, 手は $14^{\circ} 32^{\prime}$ となつている。

楕円の中点と座標の原点を結ぶ直線を分割線と すれば，左上方が短型，右下方が長型で棈円の外 周に散在している。分割線上にあり，かつ棈円の 外にあるもの(メ印) は正常型が相似的に桩大また は縮小された別型である。

なお，各点のベクトルを角度のみについてみれ ば，示数に代るものとして扱うことができる。そ れには原点から各ベクトルを延長し，X軸と平行 な直線との交点をとる。各交点に示数值をあては め, 歯種別に, 歯型別に, 示数 2 ごとの度数分布 を取ると，図 8，9，10 の右上方のグラフができ る。これら正常型のグラフは別の検定によつて正 規曲線に属することが確かめられた (表 5)。

そこで, 各歯種について, 次式を用いて正常型 の示数曲線を表わす理論值を求めた（表 6 )。
表 5 抜去歯牙 : 正常型の正規型適合度検定

\begin{tabular}{|c|c|c|c|c|c|c|}
\hline & \multicolumn{2}{|c|}{1} & \multicolumn{2}{|c|}{$\underline{2}$} & \multicolumn{2}{|c|}{$\underline{3}$} \\
\hline 示 & 理論值 & 頻数 & 理論値 & 頻数 & 理論値 & 頻数 \\
\hline$\sim 133.5$ & 8.601 & 11 & & 5) & 7.673 & 8 \\
\hline$\sim 135.5$ & 10.434 & 9 & 14.334 & $10)^{15}$ & 6.218 & 6 \\
\hline$\sim 137.5$ & 16.868 & 17 & 9.373 & 11 & 9.261 & 8 \\
\hline$\sim 139.5$ & 22.612 & 23 & 12.403 & 14 & 12.569 & 14 \\
\hline$\sim 141.5$ & 24.788 & 21 & 15.700 & 21 & 15.582 & 23 \\
\hline$\sim 143.5$ & 22.306 & 22 & 17.898 & 17 & 17.511 & 13 \\
\hline$\sim 145.5$ & 16.779 & 21 & 18.526 & 8 & 17.769 & 13 \\
\hline$\sim 147.5$ & 10.265 & 8 & 17.741 & 21 & 16.832 & 18 \\
\hline$\sim 149.5$ & 8.347 & 6) & 15.622 & 12 & 14.333 & 15 \\
\hline$\sim 151.5$ & & $2\} 9$ & 12.347 & 11 & 10.952 & 6 \\
\hline$\sim 153.5$ & & 1) & 8.927 & 7 & 7.695 & 9 \\
\hline$\sim 155.5$ & & & 6.280 & 7 & 4.961 & 8 \\
\hline$\sim 157.5$ & & & 7.850 & $11\}_{13}$ & 5.645 & $4\}_{6}$ \\
\hline$\sim 159.5$ & & & & $2)^{13}$ & & $2\}^{0}$ \\
\hline$x_{\mathrm{s}}^{2}$ & \multicolumn{2}{|c|}{4.881} & \multicolumn{2}{|c|}{13.796} & \multicolumn{2}{|c|}{8.770} \\
\hline \multirow[t]{2}{*}{$5 \%$ の $\chi_{0}^{2}$} & \multicolumn{2}{|c|}{12.592} & \multicolumn{2}{|c|}{16.919} & \multicolumn{2}{|c|}{18.307} \\
\hline & \multicolumn{2}{|c|}{$\chi_{\mathrm{s}}^{2}<\chi_{0}^{2}$} & \multicolumn{2}{|c|}{$x_{s}^{2}<x_{0}^{2}$} & \multicolumn{2}{|c|}{$x_{s}^{2}<x_{0}^{2}$} \\
\hline
\end{tabular}


表 6 抜去歯牙 : 各歯型の幅長示数の推計值

\begin{tabular}{c|c|c|c|c}
\hline & $\underline{1}$ & $\underline{2}$ & $\underline{3}$ \\
\hline \multirow{2}{*}{ 正常型 } & 二次曲線 & $\mathrm{y}=12.49 \mathrm{e}^{-\frac{\mathrm{x}^{2}}{40.54}}$ & $\mathrm{y}=9.33 \mathrm{e}^{-\frac{\mathrm{x}^{2}}{90.16}}$ & $\mathrm{y}=9.04 \mathrm{e}^{-\frac{\mathrm{x}^{2}}{84.16}}$ \\
\hline \multirow{4}{*}{ 短 } & Median & 130.00 & 130.60 & 129.25 \\
& Mean & 129.63 & 130.14 & 128.79 \\
& Mode & 130.74 & 131.52 & 130.17 \\
\hline \multirow{4}{*}{ 長 型 } & Median & 152.60 & 159.17 & 166.50 \\
& Mean & 153.50 & 159.52 & 165.34 \\
& Mode & 150.80 & 158.47 & 168.82
\end{tabular}

$\mathrm{y}=\frac{\mathrm{N}}{\sqrt{2 \pi \sigma}} \mathrm{e}^{-\frac{\mathrm{x}^{2}}{2 \sigma^{2}}}$

$\mathrm{y}$ ：横軸上 $\mathrm{x}$ 点における縦軸の高さ

$\mathrm{n}:$ 観測例数

$\sigma:$ 標準偏差

$\mathrm{x}$ ：各観測值の平均值よりの偏差

次いで, 横軸上, 中心より $\frac{\mathrm{x}}{\sigma}$ だけ離れた点に おいて実測頻数分布が正常であると仮定した場合 の理論上の高さを求め, これらの点を雲形定規で 結ぶと図 $8,9,10$ が得られる。

\section{長型, 短型の分布}

上述のように正常型の度数分布と同じく長型, 短型について 歯冠幅長示数の 度数分布を作図し た（図 8，9，10）。これによると，全歯種において， その度数分布は正常型の平均值に向つて片寄り, 正規型とはみなされないようであつた。

そこで，各曲線につき Mean, Median を求め, 大略の Mode $=$ Mean -3 (Mean-Median) 值を 求め曲線を描いた(表 6 )。

1，杰に掠いては中心寄りの曲線を描くが， $\underline{3}$ の長型においてのみ Mode 值は逆となる傾向が あるとともに，その最大值と最小值の幅も広く， 一様に分散する分布型を示した。

長型，短型の分布位置を歯種別に歯冠長，歯冠 幅の各ベクトルについて検討したところ，でで 歯冠幅が分布位置に優位に作用し， $\underline{3}$ では逆に歯 冠長が分布位置に，より大きく影響することが推 定された。ただし，1ではこのような明らかな傾 向は認められなかつた。

\section{2. 臨床的歯冠形態について}

周知のとおり，臨床的歯冠形態は歯冠に対する 歯肉の態度によつて異なる。したがつて，臨床的 歯冠形態を検討する場合には，その歯に固有の解 剖的歯冠に関する検討と歯肉に関する検討とが, 同時に行なわれなければならない。そこで本研究 では，まず，既述のように解剖的歯冠の形態的分 類基準を定めることから始め，次に，この基準で 分類した生歯の歯肉形態を検討しながら，臨床歯 冠の形態を考察することにした。

\section{臨床歯冠模型の製作}

正常歯列保有者の上顎前歯部をアルヂネート印 象材を用いて印象し，硬石膏模型を製作した（主 模型)。この模型から写真撮影用の 1 歯ごとの模 型を製作した。これを分割模型と称する。分割模 型の製作には，まず，主模型の前歯部をラバーべ 一ス印象材で複印象して副模型を製作し，次いで これを写真 2 に示すように各歯牙の長軸に平行に 歯冠の近心および遠心端で，それぞれ切断した。 分割に際して，隣在歯との接触面が破損の恐れの ある場合は隣在歯を削り，損傷した隣在歯につい ては，別に用意した副模型を用いて分割模型を製 作した。

なお，明らかに歯肉炎のあるもの，ならびに補 緅，充填を施してあるもの，および隣在歯が補緅 または欠損していて，歯肉縁形態に変化を及ぼし たと思われるものは除外した。また咬耗した歯に ついては，その程度が補正できる範囲内にとどま るものは資料として用いた。 
表 7 臨床歯冠模型 : 資料の歯型分類表

\begin{tabular}{|c|c|c|c|c|c|c|c|c|c|c|c|c|c|}
\hline \multirow{2}{*}{ 年 齢 } & \multirow{2}{*}{ 型 } & \multicolumn{6}{|c|}{ 今 } & \multicolumn{6}{|c|}{ 우 } \\
\hline & & $1]$ & \lfloor & 21 & $\lfloor 2$ & $3 !$ & $\lcm{3}$ & 11 & \lfloor & $2\rfloor$ & \lfloor & $3\rfloor^{\circ}$ & 13 \\
\hline \multirow{4}{*}{$10 \sim$} & $\mathrm{N}$ 型 & 30 & 30 & 30 & 30 & 29 & 29 & 29 & 29 & 27 & 26 & 29 & 27 \\
\hline & L 型 & 1 & 1 & 1 & 1 & 1 & 1 & 2 & 2 & 2 & 4 & 2 & 4 \\
\hline & $\mathrm{S}$ 型 & 0 & 0 & 0 & 0 & 0 & 0 & 1 & 1 & 2 & 3 & 2 & 2 \\
\hline & 計 & 31 & 31 & 31 & 31 & 30 & 30 & 32 & 32 & 31 & 33 & 33 & 33 \\
\hline \multirow{4}{*}{$20 \sim$} & $\mathrm{N}$ 型 & 32 & 33 & 31 & 32 & 32 & 32 & 31 & 30 & 35 & 32 & 36 & 36 \\
\hline & L 型 & 2 & 4 & 3 & 2 & 4 & 6 & 2 & 2 & 6 & 6 & 2 & 5 \\
\hline & $\mathrm{S}$ 型 & 8 & 6 & 4 & 5 & 3 & 3 & 4 & 4 & 1 & 5 & 2 & 1 \\
\hline & 計 & 42 & 43 & 38 & 39 & 39 & 41 & 37 & 36 & 42 & 43 & 40 & 42 \\
\hline \multirow{4}{*}{$30 \sim$} & $\mathrm{N}$ 型 & 26 & 25 & 26 & 21 & 23 & 21 & 32 & 27 & 31 & 30 & 32 & 34 \\
\hline & L 型 & 1 & 1 & 2 & 3 & 8 & 8 & 5 & 8 & 9 & 12 & 8 & 8 \\
\hline & $\mathrm{S}$ 型 & 6 & 10 & 5 & 5 & 4 & 3 & 8 & 8 & 8 & 9 & 10 & 7 \\
\hline & 計 & 33 & 36 & 33 & 29 & 35 & 32 & 45 & 43 & 48 & 51 & 52 & 51 \\
\hline \multirow{4}{*}{$40 \sim$} & $\mathrm{N}$ 型 & 21 & 22 & 23 & 21 & 21 & 17 & 24 & 23 & 23 & 25 & 28 & 24 \\
\hline & L 型 & 5 & 5 & 6 & 5 & 2 & 5 & 3 & 3 & 5 & 6 & 9 & 8 \\
\hline & $\mathrm{S}$ 型 & 1 & 1 & 5 & 4 & 2 & 3 & 5 & 6 & 6 & 4 & 4 & 7 \\
\hline & 計 & 27 & 28 & 34 & 30 & 25 & 25 & 32 & 32 & 34 & 35 & 42 & 42 \\
\hline \multirow{4}{*}{$50 \sim$} & $\mathrm{N}$ 型 & 19 & 19 & 17 & 15 & 22 & 19 & 18 & 18 & 19 & 20 & 22 & 20 \\
\hline & L 型 & 1 & 1 & 2 & 4 & 3 & 3 & 0 & 0 & 1 & 2 & 0 & 0 \\
\hline & $\mathrm{S}$ 型 & 0 & 0 & 1 & 1 & 1 & 1 & 2 & 2 & 1 & 2 & 0 & 1 \\
\hline & 計 & 20 & 20 & 20 & 20 & 26 & 23 & 20 & 20 & 21 & 24 & 22 & 21 \\
\hline \multirow{4}{*}{$60 \sim$} & $\mathrm{N}$ 型 & 5 & 4 & 6 & 7 & 9 & 7 & 4 & 4 & 4 & 4 & 4 & 4 \\
\hline & L 型 & 2 & 2 & 2 & 2 & 0 & 1 & 0 & 0 & 0 & 0 & 0 & 0 \\
\hline & $\mathrm{S}$ 型 & 1 & 2 & 1 & 0 & 0 & 0 & 0 & 0 & 0 & 0 & 0 & 0 \\
\hline & 計 & 8 & 8 & 9 & 9 & 9 & 8 & 4 & 4 & 4 & 4 & 4 & 4 \\
\hline 小 & 計 & 161 & 166 & 165 & 158 & 164 & 159 & 170 & 167 & 180 & 190 & 193 & 193 \\
\hline 合 & 計 & \multicolumn{6}{|c|}{973} & \multicolumn{6}{|c|}{1093} \\
\hline
\end{tabular}

したがつて，本研究に用いた臨床歯冠すなわち 分割模型の内訳は， o 973 歯, ㅇ 1093 歯, 計 2066 歯となる。また，これらを年齢別にすれば表 7 に 示すとおりとなる。

臨床的歯冠の計測部位および計測方法(図 2)

1) 歯冠の最大幅径(B)

歯冠軸に直角な歯冠の最大幅

2) 歯冠の最大長 (L)
歯冠軸に平行な臨床的歯冠の最大長

3）近心歯間乳頭頂の位置（a),(c)

歯肉の最深点において歯冠軸に直交する直線と 近心歯肉乳頭頂との距離 $\mathrm{a}$ ，ならびに，切縁線か らの距離 $\mathrm{c}$

4）遠心歯間乳頭頂の位置(b)，(d)

同上遠心歯間乳頭頂の距離 (b)，ならびに，切 縁線からの距離 $\mathrm{d}$ 

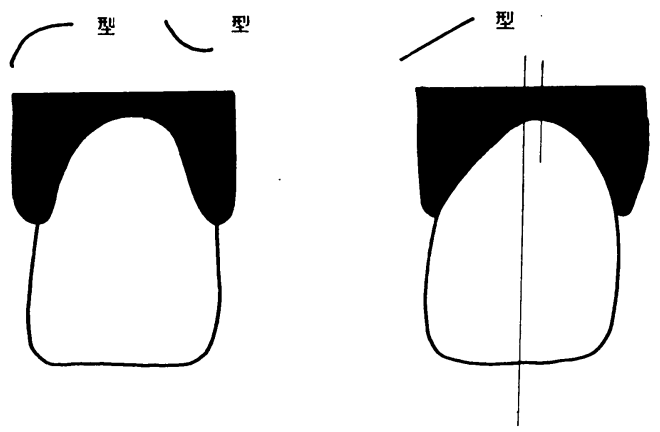

図 11 歯肉縁の形態と最梁部位

5）歯肉の最哚点の位置および歯肉縁の形態 正常歯肉の遊離縁は普通, 歯牙の歯頸線にほぼ 一致して, 近心側歯間乳頭から遠心側歯間乳頭に わたつて最深点を下方に向けた一定の凹彎をして いる。この彎曲は歯冠軸を中央にして近心側, 遠 心側で，かなり細かく変化している。しかし取扱 いのつごうで, この彎曲の形態を近心側, 遠心側 に分け,さらに，その形態を直線型，凹型，凸型 の 3 種に分類した(図 11)。

また, 最深点の位置についても各歯牙の歯冠軸 に対し，その部位が近心側にあるか，遠心側にあ るか，歯冠軸上にあるかの 3 型に分類し，最深点 と歯冠軸との距離を測定した。

\section{解剖的歯冠形態の分類基準 (既述) による臨床 歯冠資料の分類}

歯牙萠出後, 歯冠幅は変らないが, 臨床的歯冠 長は歯牙の萠出によつて順次変化する。しかし， 前段で述べた 解剖的歯冠の 正常型の 検討に 際し て適用した棄却楕円法を利用することによつて， 各年齢階級に応ずる臨床的歯冠形態を推定し, 臨 床歯冠資料についても，これが正常型か否かの分 類を行なうことが可能である。図 $12,13,14$, 15，16，17は，上記の目的のために作製した臨床 歯冠の各年代に応ずる形態分類図である。この図 は利用の便のために合成したものであるが，これ によつて, 年齢, 臨床的歯冠長, 歯冠幅の平均值 から各被検歯の歯冠形態の分類が行なわれる。

さて, 図 18,19 は全資料の 臨床的歯冠長を測 定し, 階級幅 1 年として平均值を求め, Grubbs の 菓却検定法により資料を整したうえ, 得られた年

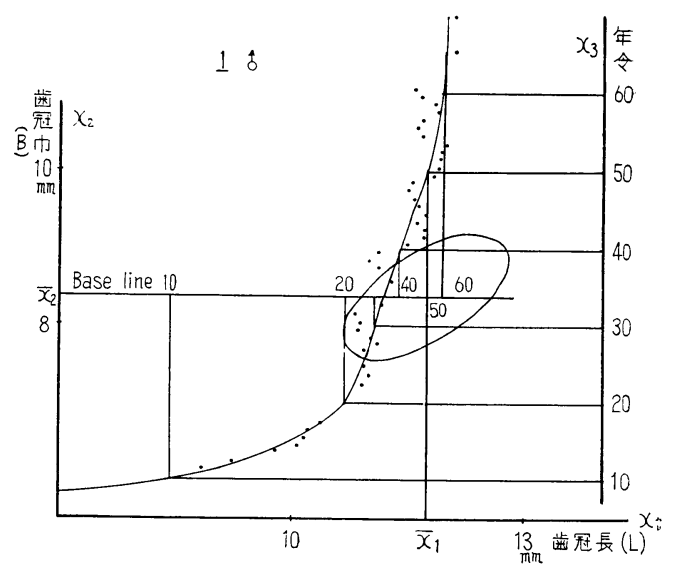

図 11 解剖的歯冠形態の 分類基準による臨床 歯冠資料の分類図

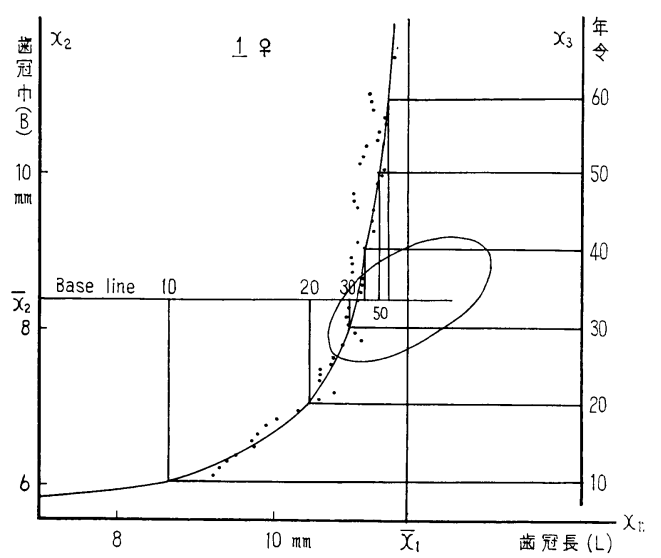

図 13 解剖的歯冠形態の 分類基準による 臨床歯冠資料の分類図

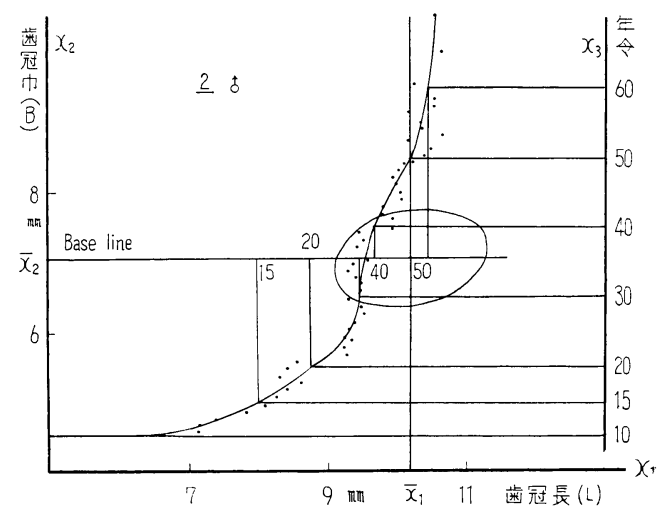

図 14 解剖的歯冠形態の 分類基準による 臨床歯冠資料の分類困 


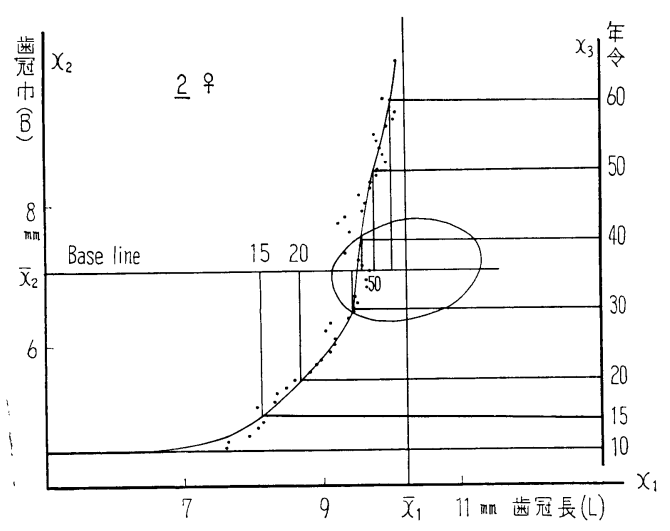

図 15 解剖的歯冠形態の 分類基準による 臨床歯冠資料の分類図

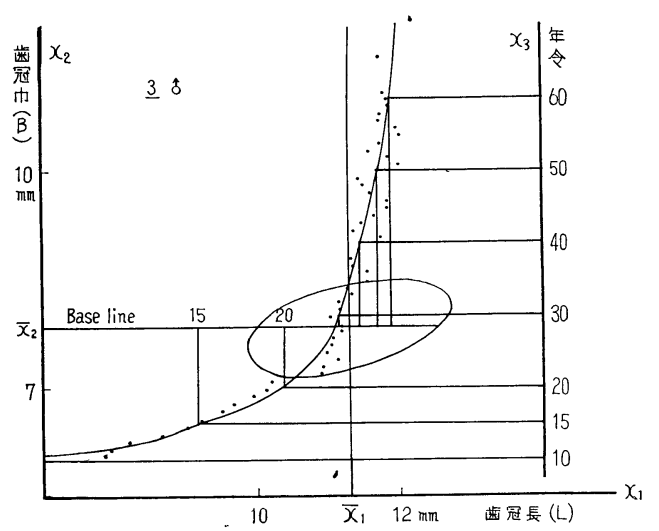

図 16 解剖的歯冠形態の 分類基淮による 臨床歯冠資料の分類図

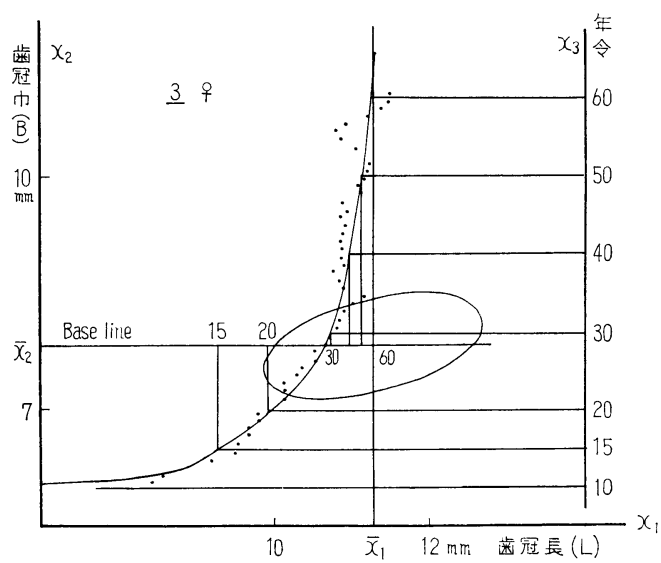

図 17 解剖的歯冠形態の 分類基準による 臨床歯冠資料の分類図

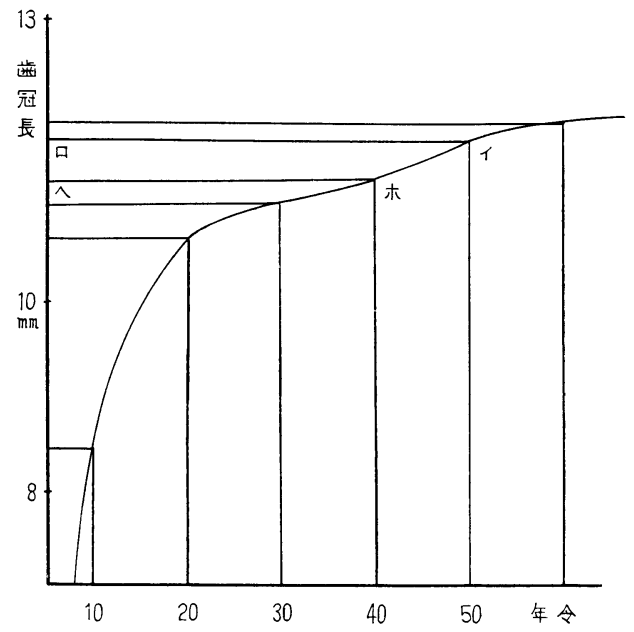

図 18 1 合の臨床歯冠長一年齢曲線

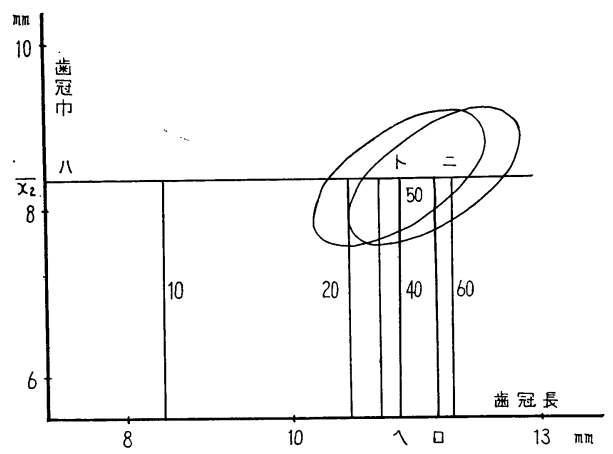

図 19 各年代の臨床歯冠正常型の 存在範囲

齢一臨床歯冠長曲線である。

いま，その歯が 50 歳の年齢のものであつたと する。この年齢に応ずる歯冠長の平均值はイから ロとして求められる。ほかに，正常型歯冠幅の平 均值は八にある。座標口および八であらわされる 点は 50 歳の人の持つ 正常型の解剖的歯冠の存在 範囲を示す $5 \%$ 棄却楕円の中心ニとなる。言いか えれば，この棈円は，さきに用いた解剖的歯冠形 態の正常型の場合と同じ長径および短径，角度を 持つ。

もし，この歯が $5 \%$ 棄却楕円の外にある歯冠幅 を持つていたとすれば，それは 50 歳の年齢にお いて正常型以外のもの，すなわち長型，短型のい ずれかに属するものである。同様のことが，臨床 
表 8 臨床歯冠模型 : 左右差の検定表 (30 49 歳)

\begin{tabular}{|c|c|c|c|c|c|c|c|c|c|}
\hline & & $\overline{\mathrm{x}}$ & $\mathrm{u}^{2}$ & $\mathrm{~F}_{\mathrm{s}}$ & $\mathrm{F}_{\mathrm{n} 1}^{\mathrm{n}_{2}} 0.05$ & $\mathrm{w}^{2}$ & $\left|t_{s}\right|$ & $\operatorname{Prt}_{\mathrm{r}}(0.05)$ & Sig \\
\hline \multirow{3}{*}{$\hat{0}$} & $\underline{1}$ & $\begin{array}{l}131.70 \\
131.04\end{array}$ & $\begin{array}{l}20.10 \\
13.76\end{array}$ & 1.460 & $\begin{array}{l}1.62 \\
\sigma_{1}=\sigma_{2}\end{array}$ & 16.93 & 0.780 & $\begin{array}{c}1.980 \\
\mathrm{~m}_{1}=\mathrm{m}_{2}\end{array}$ & $(-)$ \\
\hline & $\begin{array}{l}\frac{2}{2} \\
2 \\
\end{array}$ & $\begin{array}{l}136.95 \\
136.93\end{array}$ & $\begin{array}{l}26.28 \\
24.16\end{array}$ & 1.088 & $\begin{array}{c}1.64 \\
\sigma_{1}=\sigma_{2}\end{array}$ & 25.13 & 0.014 & $\begin{array}{c}1.980 \\
\mathrm{~m}_{1}=\mathrm{m}_{2}\end{array}$ & $(-)$ \\
\hline & $\frac{33}{3 !}$ & $\begin{array}{l}138.40 \\
138.84\end{array}$ & $\begin{array}{l}23.82 \\
18.53\end{array}$ & 1.286 & $\begin{array}{c}1.68 \\
\sigma_{1}=\sigma_{2}\end{array}$ & 20.98 & 0.434 & $\begin{array}{c}2.000 \\
\mathrm{~m}_{1}=\mathrm{m}_{2}\end{array}$ & $(-)$ \\
\hline \multirow{3}{*}{ 우 } & $\frac{1}{1}$ & $\begin{array}{l}130.48 \\
130.36\end{array}$ & $\begin{array}{l}16.21 \\
18.26\end{array}$ & 1.126 & $\begin{array}{l}1.61 \\
\sigma_{1}=\sigma_{2}\end{array}$ & 17.29 & 0.157 & $\begin{array}{c}1.980 \\
\mathrm{~m}_{1}=\mathrm{m}_{2}\end{array}$ & $(-)$ \\
\hline & $\begin{array}{l}\frac{2}{2} \\
2\end{array}$ & $\begin{array}{l}135.31 \\
135.01\end{array}$ & $\begin{array}{l}36.82 \\
32.84\end{array}$ & 1.121 & $\begin{array}{c}1.58 \\
\sigma_{1}=\sigma_{2}\end{array}$ & 34.85 & 0.264 & $\begin{array}{c}1.980 \\
\mathrm{~m}_{1}=\mathrm{m}_{2}\end{array}$ & $(-)$ \\
\hline & $\frac{3}{3 !}$ & $\begin{array}{l}138.37 \\
137.64\end{array}$ & $\begin{array}{l}20.92 \\
28.37\end{array}$ & 1.356 & $\begin{array}{c}1.58 \\
\sigma_{1}=\sigma_{2}\end{array}$ & 24.71 & 0.799 & $\begin{array}{c}1.980 \\
\mathrm{~m}_{1}=\mathrm{m}_{2}\end{array}$ & $(-)$ \\
\hline
\end{tabular}

的歯冠長の測定值についても言える。このように して, 臨床的歯冠資料が長型, 正常型, 短型のい ずれかに分類された。

次いで，40 歳の年齢の歯について考えれば，こ の年齢に応ずる 歯冠長の 平均值は 50 歳同様ホか らへとして求められる。また, 正常型歯冠幅の平 均値は年齔により変化しないので八にある。座標 のへおよび八で示される点を中心にして, 50 歳と 同じ $5 \%$ の菓却楕円を描けば, 40 歳の人の持つ正 常型の臨床的歯冠の存在範囲を知ることができ， 歯型を分類することが可能となる。

30 歳, 20 歳等の任意の 年齢の 歯について, 前 述の方法で, 正常型の臨床的歯冠の存在範囲を決 定することができる。すなわち, 正常型の歯冠幅 の平均值八の直線を Base line として, その直線 上を棈円の中心が各年齢ごとに移動することによ り解決される。

上記の分類法により資料を各歯型に分類した。 各歯種についての正常型, 長型, 短型を年代別に 表わしたものを表 7 に示した。

\section{臨床歯冠示数の左右差}

抜去歯牙で歯冠の概形を検討するのに歯冠の幅 長示数を用いた。同様に，臨床歯冠でも歯冠幅に 対する臨床歯冠の長さの比を用いた。以下，これ を臨床歯冠示数という。

ところで，ある個体の歯冠幅では萠出後の変化
がほとんどないが，臨床歯冠長は萠出後，増令的 に変化する。したがつて, 臨床歯冠示数も増令的 に変化する。しかし，その変化の程度はある間隔 の年齢時期によつて異なる。このうち比較的臨床 歯冠長の変化の少ない時期, つまり, 示数が大き く変動しない時期をみると，図 12，13，14，15， 16，17でもわかるとおり，これは各歯種ともだ いたい 30〜 49歳までにある。この時期を一応, 停止期として，まず，停止期にある正常型群の歯 冠幅長示数の左右差を検討した。

その結果は表 8 に示すとおりで，各歯種におい て左右の 歯冠幅長示数に 有意差がないと判定し た。そこで, 左右の歯牙を合同して以下の推計を 行なうこととした。

左右差のみならず図 $20,21 ，$ 表 9 でわかるよう に，30 49 歳の時期の 臨床歯冠示数の 分布で 正 常型については正規型をなし，その平均值は，抜 去歯牙における解剖的歯冠幅長示数の正常型群の 平均值と，ほぼ 10 以下の差にとどまつた。この 差は実長にして $0.8 \mathrm{~mm}$ 以下にすぎない。この ことから，30〜49歳の年齢時期にある歯はほとん ぞ解剖学的歯冠の全体が萠出し終つている状態に あるとみることができる。

\section{歯冠幅長示数の増令的变化}

正常歯冠形態群について，1歳ごとに臨床歯冠 示数の平均值を求め，これを図示すると図 $22 \sim 27$ 


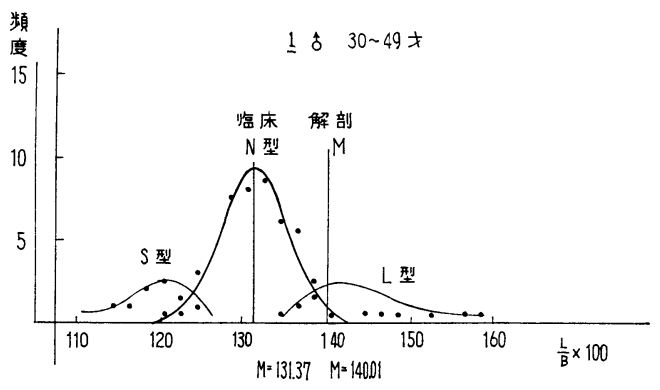

図 20 臨床歯冠の幅長示数の 分布図

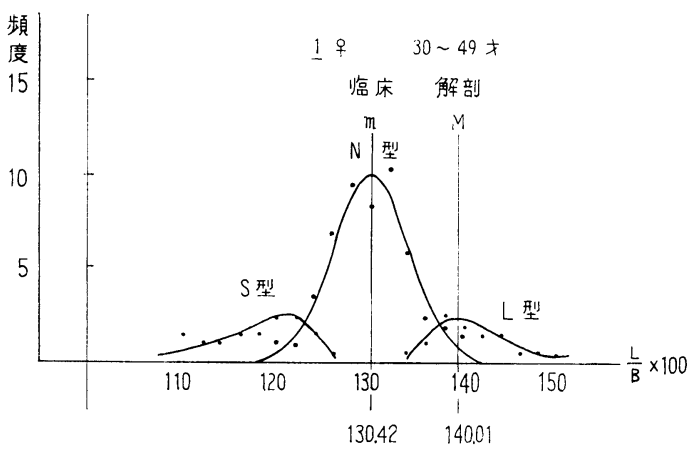

図 21 臨床歯冠の幅長示数の 分布図 表 9 臨床歯冠模型: 正常型(30４9 歳)の諸推計値表

\begin{tabular}{|c|c|c|c|c|c|c|}
\hline & \multicolumn{3}{|c|}{ 今 } & \multicolumn{3}{|c|}{ 우 } \\
\hline & 1 & $\underline{2}$ & $\underline{3}$ & 1 & $\underline{2}$ & $\underline{3}$ \\
\hline $\mathrm{N}$ & 94 & 91 & 82 & 106 & 109 & 118 \\
\hline$\overline{\mathrm{x}}=$ 示数 & 131.37 & 136.94 & 138.64 & 130.42 & 135.16 & 138.00 \\
\hline $\mathrm{u}^{2}$ & 16.92 & 24.86 & 20.74 & 17.12 & 34.54 & 24.67 \\
\hline 95\%信頼限界 & $\begin{array}{c}132.21 \geqq \\
\mathrm{~m} \\
\geqq 130.53\end{array}$ & $\begin{array}{c}137.98 \geqq \\
\mathrm{~m} \\
\geqq 135.90\end{array}$ & $\begin{array}{l}139.64 \geqq \\
\mathrm{~m} \\
\geqq 137.64\end{array}$ & $\begin{array}{c}131.21 \geqq \\
\mathrm{~m} \\
\geqq 129.62\end{array}$ & $\begin{array}{c}136.27 \geqq \\
\mathrm{~m} \\
\geqq 134.05\end{array}$ & $\begin{array}{c}138.90 \geqq \\
\mathrm{~m} \\
\geqq 137.10\end{array}$ \\
\hline 5\%亲却限界 & $\begin{array}{r}139.58 \geqq \\
\quad x_{0} \\
\geqq 123.17\end{array}$ & $\begin{array}{r}146.91 \geqq \\
\quad x_{0} \\
\geqq 126.97\end{array}$ & $\begin{array}{r}147.75 \geqq \\
\mathrm{x}_{0} \\
\geqq 129.52\end{array}$ & $\begin{array}{r}138.66 \geqq \\
x_{0} \\
\geqq 122.17\end{array}$ & $\begin{array}{c}146.87 \geqq \\
\mathrm{x}_{0} \\
\geqq 123.44\end{array}$ & $\begin{array}{c}147.87 \geqq \\
x_{0} \\
\geqq 128.13\end{array}$ \\
\hline $5 \%-\chi^{2}-$ Test & $x_{s}^{2}<x_{0}^{2}$ & $\chi_{s}^{2}<\chi_{0}^{2}$ & $\chi_{s}^{2}<x_{0}^{2}$ & $x_{\mathrm{s}}^{2}<x_{0}^{2}$ & $\chi_{s}^{2}<\chi_{0}^{2}$ & $\chi_{\mathrm{s}}^{2}<\chi_{0}^{2}$ \\
\hline 正 規 曲 線 & $9.19 \mathrm{e}^{-\frac{\mathrm{x}^{2}}{33.28}}$ & $7.38 \mathrm{e}^{-\frac{\mathrm{x}^{2}}{48.41}}$ & $7.23 \mathrm{e}^{-\frac{\mathrm{x}^{2}}{40.98}}$ & $10.16 \mathrm{e}^{-\frac{\mathrm{x}^{2}}{34.65}}$ & $7.29 \mathrm{e}^{-\frac{\mathrm{x}^{2}}{71.10}}$ & $9.34 e^{-\frac{x^{2}}{50.78}}$ \\
\hline 解剖幅長示数との差 & 10.10 & 7.51 & 5.38 & 10.05 & 9.29 & 6.02 \\
\hline 歯肉の被蓋 mm & 0.84 & 0.53 & 0.42 & 0.84 & 0.66 & 0.47 \\
\hline
\end{tabular}

が得られる。

a） 1 の示数一年龄曲線（図 22，23）

男性では，約 7 歳頃より 12 歳頃まで直線的に 急激なる示数の上昇を示す。ただし，分散はかな り大きく，個人差が相当あることを思わせた。次 いで 20 歳より 50 歳までは示数の上昇が横ばいと なり $(123.5 \sim 135.0), 50$ 歳頃から先は再び徐々 に上昇化する傾向がある。そして臨床歯冠示数が 抜去歯牙における 平均幅長示数 140.47 に到達す るのは，この資料では約 60 歳に相当していた。

10 歳ごとの年齢時期で, その時の臨床歯冠の長 さ，言いかえれば歯肉の高さを歯冠幅 $8.36 \mathrm{~mm}$ (平均)として示数から換算すると図 22,23 の右
上の歯面図のようになる。

女性については，男性と同じく萠出期は約 7 歳 前後で，そのご，10 26 歳頃まで直線的示数の急 上昇を示すが，12 歳頃を境として，それ以前より 以後の方がわずかに上昇率が下がる。以後 50 歳 頃までは，ほとんど変化がなく，歯冠の萠出変化 は認められない。そして 50 歳以後, 再び上昇し 始め, 歯冠の完全露出するのは 65 歳頃となる。

なお男女差について, 示数の増令的変化は全般 的には有意差はないが，傾向として 13 歳以後， 女性が徐々に萠出するに比べ，男性はわずかでは あるが女性より萠出示数が高い。これが約 30 歳前 後まで続き，30 歳でほぼ一致するが，そのご，再 


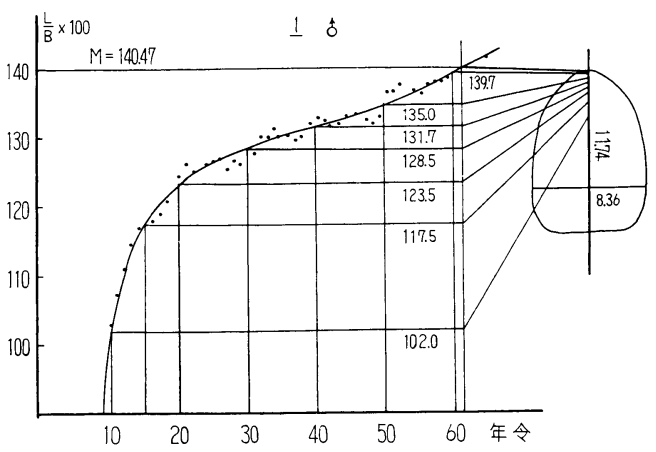

図 22 臨床歯冠 : 歯冠幅長示数の 増令的変化

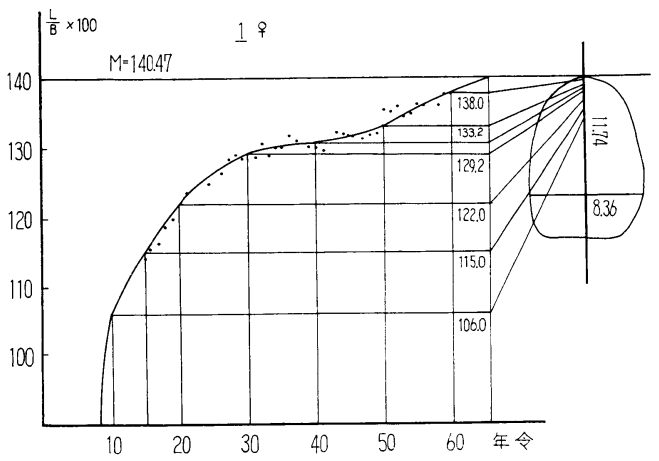

図 23 臨床歯冠 : 歯冠幅長示数の 増令的変化

び男性が女性より高い示数值を示し続ける。その 間，女性で目だつことは 30 歳以後の平行期が約 10 年くらいあるのに対して，男性では明瞭な平 行期は認められないことである。

歯冠の完全露出の時期は，この資料に関する限 り，女性が約 5 年男性よりおそい。

b） 2の示数一年齢曲線（図 24，25）

男性の萠出は 8 歳より 9 歳頃となり，示数 100 すなわち歯冠幅と歯冠長が同数值をとる時期は約 10 歳である。1 と同様，急激なる 萠出曲線は 14 歳頃まで続き, 以後 34 歳ぐらいまで徐々に上昇す る。そして比較的変化の少ない時期は 35 歳〜 50 歳ぐらいまであり，その期間は1に比べて短く， しかも，おそい時期にくる。50 歳以後，再び歯肉 の後退が行なわれ，全歯冠の露出期は 58 歳頃で ある。

女性の萠出期は男性より約 1 年早く, 8 歳頃で 男性の萠出曲線を一年前にずらしたと同じ上昇曲

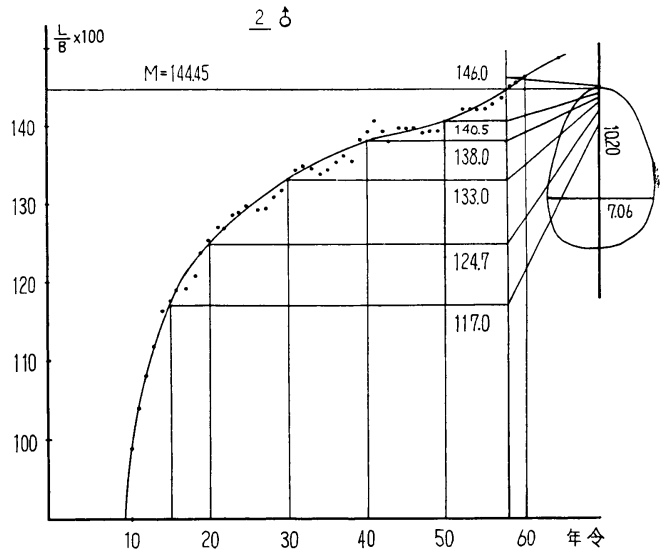

図 24 臨床歯冠 : 歯冠幅長示数の 増令的変化

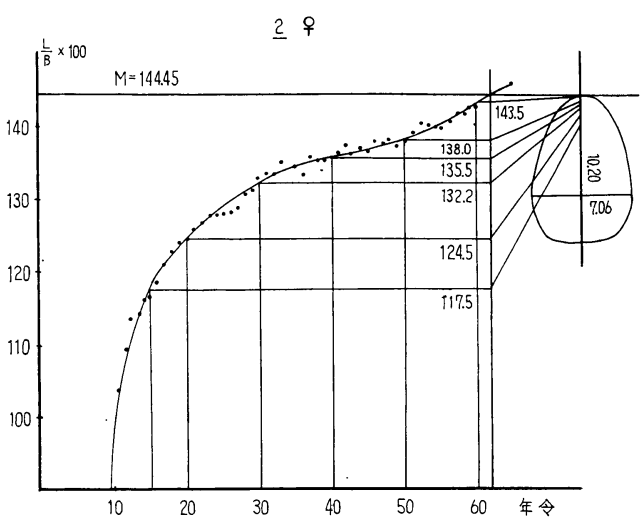

図 25 臨床歯冠 : 歯冠幅長示数の 増令的変化

線を示す。変化の少ない時期は 30〜50 歳までで, 男性の場合より停止期の区別が明瞭である。完全 萠出は 62 歳頃で, 男性との差が約 4 年である。 なお，男女差の一般的傾向として女性の萠出が 一年早いため，20 歳までは 常に女性の示数が高 く，18 歳〜25 歳までは同数值をとるが，以後は， 逆に男性が女性より高くなる。，女性における 30 〜 50 歳代のいわゆる停止期 は比較的はつきり認 められる。

c） 3 の示数一年齢曲線（図 26,27）

男性，女性とも，その萠出期は 10 歳頃である が, 女性の萠出示数は男性よりはるかに高い。すな わち，15 歳において示数差は 5.0 の開きがあり， 両曲線が交差する 時期は約 25 歳で, 以後, 男性 の萠出示数が高くなるが， $1 ， \underline{2}$ において見られ 


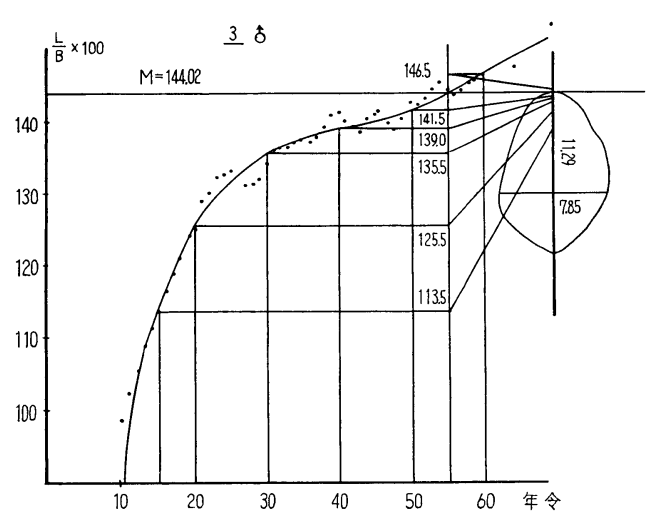

図 26 臨床歯冠 : 歯冠幅長示数の 増令的変化

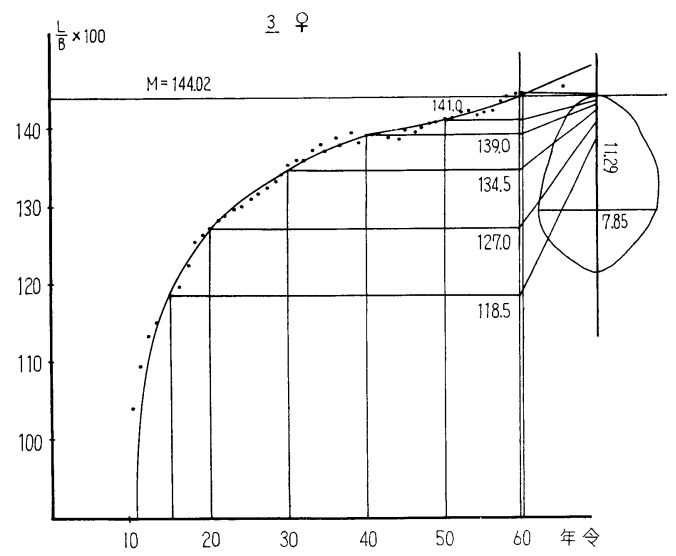

図 27 臨床歯冠: 歯冠幅長示数の 増令的変化

るほどの差はなく，両曲線の示数差は 1.0 以内で ある。定常期は 50 歳頃まで徐々に続き，これを過 ぎると再び上昇する。そのごの上昇率は男性が高 く, 完全に歯冠の露出する時期は男性では 55 歳, 女性では 60 歳であり，龷，杰に比べて 3 が最も早 い時期に完全露出する。

\section{歯間乳頭の増令的変化について}

臨床的歯冠長とならんで，歯間乳頭の高さは歯 牙の萠出, 歯肉の退縮に伴なつて増令的に変化す る。そこで, 研究方法の項で述べたとおり, 歯間 乳頭頂の位置を切縁 (尖頭) 線および歯肉の最深 点よりの距離で表わし，両測定值をそれぞれ対応 する歯冠幅で除して, 近心および遠心歯間乳頭示 数, 近心および遠心歯肉形態示数とし，これらの 示数の増令的変化を示数一年齢曲線として検討し

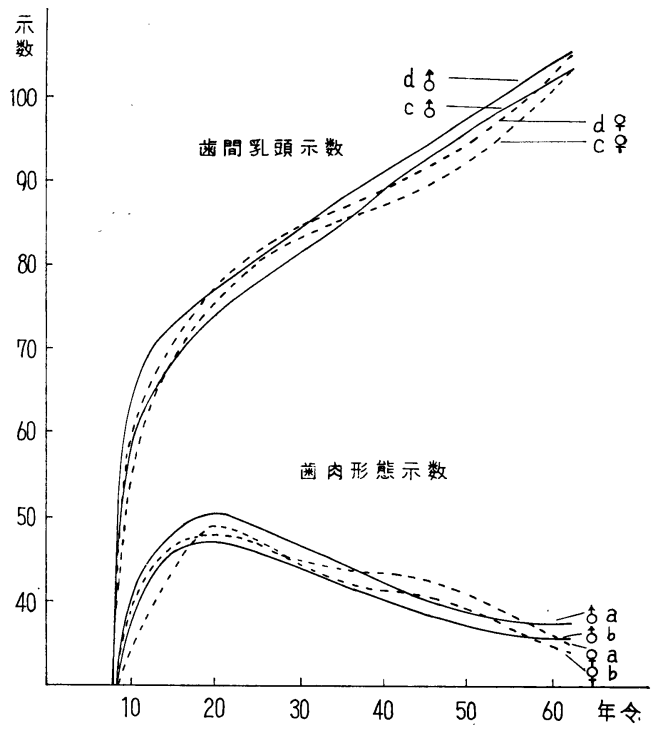

図 28 臨床歯冠: 歯間乳頭の増令的変化 $\underline{1}$ (性差)

た。

図 28 上は1の歯間乳頭示数一年齢曲線である が，全般的曲線経過は臨床歯冠示数に関するもの とほぼ同様である。しかし臨床歯冠示数では男女 とも停止期に相当したものが明瞭にあつたが，歯 間乳頭示数では男性に明瞭でなく女性のみに認め られた。なお，年齢，性別に関係なく常に認めら れたのは，遠心乳頭示数が近心のそれより高い值 を示したことである。

図 28 下 は同じく 1 の歯肉形態示数一年齢曲線 である。この示数は歯牙が萠出を開始してょり 20 歳ぐらいまでは上昇を続け，そのご，50歳ぐら いまで漸減し，以後，やや横ばい状態となる。そ の間, 特に女性では 30 45 歳までの間に変化の ほとんどない，いわゆる停止期がある。このよう に歯肉形態示数が年齢時期により増減すること は,この示数が単なる臨床歯冠長と切縁から歯間 乳頭頂までの距離との差をなすものではなく，歯 肉の最深点と近心および遠心乳頭頂間の位置的関 係の年齢的推移を追求する目じるしとなる。

2でも1とほぼ同様の示数一年齢曲線(図 29)を なすが，歯間乳頭示数の近遠心差が1よりやや大 きい。これは歯冠軸の傾斜が中切歯より, 側切歯 


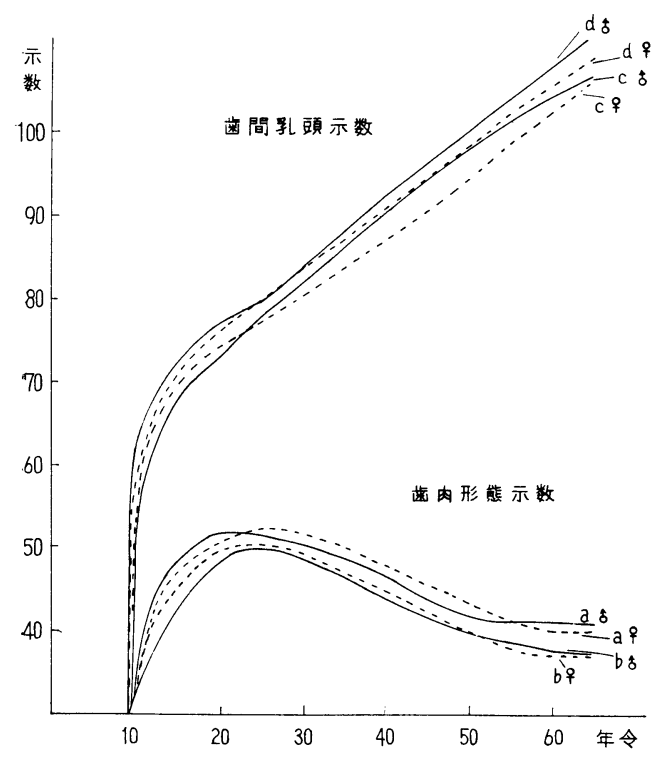

図 29 臨床歯冠 : 歯間乳頭の 増令的変化 $\underline{2}$ (性差)

のほうが強いことによると思われる。

また，歯肉形態示数では1におけるほどの性差 が認められない。

杰の示数一年齢曲線（図 30）で歯間乳頭示数は 30 歳までは男女差は認められない。30 歳以後 12 同様，いくぶん男性の示数が高くなるが差は少な い。歯肉形態示数については 20 歳までは女性が 高い值を続ける。また，女性では 20 歳〜30 歳ま で約 10 年間全く示数の変化を諗めない停止期が ある。これに反し，男性が最高值を示すのは 22 , 23 歳頃で女性よりややおそく, また, 高い彎曲度 を示すが，以後，直線的に下降し 50 歳頃より変 化がないか，または，いくぶん上昇し始める。な お，近遠心の差は 12 に示されたよりもさらに低 い值であつた。

\section{歯肉縁形態と最深部位}

正常歯肉縁は一定の凹彎曲をしているが, その 彎曲は細部について 検討すれば種々変化してい る。その彎曲の形態は歯冠軸を分割線として近心 側, 遠心側に分け, さらに, その形態を肉眼的に 直線型，凹型，凸型の 3 種に分類した（図 11）。 最深部位についても各歯牙の歯冠軸を基準線と し，その部位が近遠心いずれにあるか，また，そ

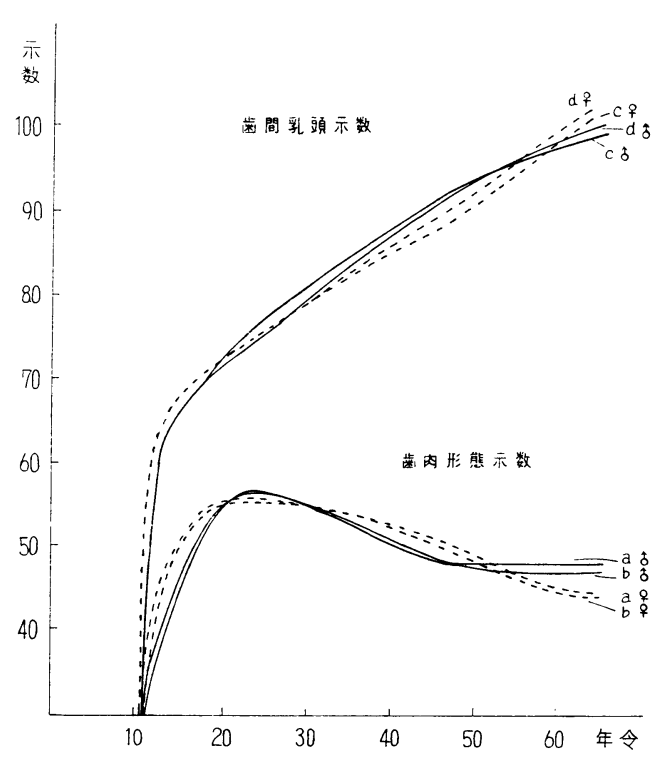

図 30 臨床歯冠 : 歯間乳頭の 増令的変化 $\underline{3}$ (性差)

の歯冠軸よりの距離を写真, 模型の両方を検討し ながら計測した。

i） 1 について（表 10, 11）

男性の近心側は各年代とも20 歳代を 除き, 凹 型が 80 \%以上を吕めている。そして 20 歳代では 凹型が $66.2 \%$ となり，これにかわつて 直線型が 多くなつている。特に, 40 歳代以上は凹型が $90 \%$ 以上となり，凸型が全く見うけられなかつた。

遠心側についても近心側と同じく20歳代が $78.5 \%$ となる以外，全年踰において $90 \%$ 以上が 凹型を示し，その占める割合は近心側よりも凹型 が多い。

最深部位については，10 歳代が遠心寄り $80 \%$ で最高となり，20 歳代では正中線上が $61.5 \%$ で, 遠心寄りが $37 \%$ と少なくなる。30 歳代以後は再 び遠心寄りが多くなるが, その距離については 10 歳代の遠心寄り $0.68 \mathrm{~mm}$ が最高で平均 $0.4 \mathrm{~mm}$ である。1において近心寄りとなるものが $5 \%$ 以 下で非常に少なくなつている。

女性の近心側の特長は 10 歳代で非常に変化が あり，萠出期における歯肉縁の不安定を示してい る。20 歳以後は約 80 \%以上が凹型である。遠心 
表 10 歯肉縁形態の分類表

今 1 （）内は\%を示し，十は最深部位の近心寄り，一は最深部位の遠心寄り

\begin{tabular}{|c|c|c|c|c|c|c|c|c|c|c|c|c|c|c|}
\hline \multicolumn{3}{|c|}{ 年 齢 } & \multicolumn{2}{|r|}{10} & \multicolumn{2}{|r|}{20} & \multicolumn{2}{|r|}{30} & \multicolumn{2}{|r|}{40} & \multicolumn{2}{|r|}{50} & \multicolumn{2}{|r|}{60} \\
\hline \multirow{6}{*}{$\begin{array}{l}\text { 歯 } \\
\text { 肉 } \\
\text { 縁 } \\
\text { 形 } \\
\text { 態 }\end{array}$} & 近 & $\frown$ & 50 & (83.3) & 43 & $(66.2)$ & 42 & $(82.4)$ & 39 & $(90.7)$ & 36 & $(94.7)$ & 9 & $(100.0)$ \\
\hline & 心 & $\smile$ & 1 & $(1.7)$ & 6 & $(9.2)$ & 1 & $(1.9)$ & 0 & $(0.0)$ & 0 & $(0.0)$ & 0 & $(0.0)$ \\
\hline & 側 & - & 9 & $(15.0)$ & 16 & $(24.6)$ & 8 & (15.7) & 4 & $(9.3)$ & 2 & $(5.3)$ & 0 & $(0.0)$ \\
\hline & 遠 & $\frown$ & 57 & $(95.0)$ & 51 & $(78.5)$ & 47 & $(92.2)$ & 40 & $(93.0)$ & 37 & (97.4) & 9 & $(100.0)$ \\
\hline & 心 & $\smile$ & 0 & $(0.0)$ & 4 & $(6.2)$ & 1 & $(2.0)$ & 0 & $(0.0)$ & 0 & $(0.0)$ & 0 & $(0.0)$ \\
\hline & 側 & - & 3 & $(5.0)$ & 10 & $(15.3)$ & 3 & $(5.9)$ & 3 & $(7.0)$ & 1 & $(2.6)$ & 0 & $(0.0)$ \\
\hline 最 & 近 & 心 & 2 & $(3.3)$ & 1 & $(1.5)$ & 0 & $(0.0)$ & 0 & $(0.0)$ & 2 & $(5.3)$ & 0 & $(0.0)$ \\
\hline 深 & 正 & 中 & 10 & $(16.7)$ & 40 & $(61.5)$ & 14 & $(27.5)$ & 15 & $(34.9)$ & 8 & (21.1) & 2 & $(22.2)$ \\
\hline 部 & 遠 & 心 & 48 & $(80.0)$ & 24 & $(37.0)$ & 37 & $(72.5)$ & 28 & $(65.1)$ & 28 & $(73.6)$ & 7 & $(77.8)$ \\
\hline 位 & 平 & 離 & & $.56 \mathrm{~mm}$ & & $.14 \mathrm{~mm}$ & & $.33 \mathrm{~mm}$ & & $.21 \mathrm{~mm}$ & & $26 \mathrm{~mm}$ & & $.40 \mathrm{~mm}$ \\
\hline
\end{tabular}

表 11 歯肉縁形態の分類表

우 1 （）内は\%を示し，十は最深部位の近心寄り，一は最深部位の遠心寄り

\begin{tabular}{|c|c|c|c|c|c|c|c|c|c|c|c|c|c|c|}
\hline \multicolumn{3}{|c|}{ 年 齢 } & \multicolumn{2}{|r|}{10} & \multicolumn{2}{|r|}{20} & \multicolumn{2}{|r|}{30} & \multicolumn{2}{|r|}{40} & \multicolumn{2}{|r|}{50} & \multicolumn{2}{|r|}{60} \\
\hline \multirow{6}{*}{$\begin{array}{l}\text { 歯 } \\
\text { 肉 } \\
\text { 縁 } \\
\text { 形 } \\
\text { 態 }\end{array}$} & 近 & $\frown$ & 27 & $(46.6)$ & 48 & $(78.7)$ & 50 & $(84.7)$ & 46 & $(97.9)$ & 36 & $(100.0)$ & 8 & $(100.0)$ \\
\hline & 心 & $\smile$ & 17 & (29.3) & 3 & $(4.9)$ & 1 & $(1.7)$ & 0 & $(0.0)$ & 0 & $(0.0)$ & 0 & $(0.0)$ \\
\hline & 側 & - & 14 & $(24.1)$ & 10 & $(16.4)$ & 8 & (13.6) & 1 & $(2.1)$ & 0 & $(0.0)$ & 0 & $(0.0)$ \\
\hline & 遠 & $\frown$ & 48 & $(82.8)$ & 54 & $(88.5)$ & 54 & $(91.5)$ & 47 & $(100.0)$ & 36 & $(100.0)$ & 8 & $(100.0)$ \\
\hline & 心 & $\smile$ & 2 & $(3.4)$ & 3 & $(4.9)$ & 0 & $(0.0)$ & 0 & $(0.0)$ & 0 & $(0.0)$ & 0 & $(0.0)$ \\
\hline & 側 & - & 8 & (13.8) & 4 & $(6.6)$ & 5 & $(8.5)$ & 0 & $(0.0)$ & 0 & $(0.0)$ & 0 & $(0.0)$ \\
\hline \multirow{5}{*}{$\begin{array}{l}\text { 最 } \\
\text { 深 } \\
\text { 部 } \\
\text { 位 }\end{array}$} & 近 & 心 & 4 & $(6.9)$ & 0 & $(0.0)$ & 1 & $(1.7)$ & 2 & $(4.3)$ & 1 & $(2.8)$ & 0 & $(0.0)$ \\
\hline & 正 & 中 & 28 & $(48.3)$ & 19 & $(31.1)$ & 22 & $(37.3)$ & 13 & $(27.7)$ & 18 & $(50.0)$ & 6 & $(75.0)$ \\
\hline & 遠 & 心 & & $(44.8)$ & 42 & $(68.9)$ & 36 & $(61.0)$ & 32 & (68.1) & 17 & $(47.2)$ & 2 & $(25.0)$ \\
\hline & \multicolumn{2}{|c|}{ 平均距離 } & \multicolumn{2}{|c|}{$-0.15 \mathrm{~mm}$} & \multicolumn{2}{|c|}{$-0.35 \mathrm{~mm}$} & \multicolumn{2}{|c|}{$-0.28 \mathrm{~mm}$} & \multicolumn{2}{|c|}{$-0.27 \mathrm{~mm}$} & \multicolumn{2}{|c|}{$-0.25 \mathrm{~mm}$} & \multicolumn{2}{|c|}{$-0.09 \mathrm{~mm}$} \\
\hline & \multicolumn{2}{|c|}{ 今 $\underline{2}$} & \multicolumn{12}{|c|}{$\begin{array}{c}\text { 表 } 12 \text { 歯肉縁形態の分類表 } \\
\text { （）内は\%を示し，＋は最深部位の近心寄り，一は最深部位の遠心寄り }\end{array}$} \\
\hline \multicolumn{2}{|c|}{$\cdots \cdots$} & 年 齢 & \multicolumn{2}{|r|}{10} & \multicolumn{2}{|r|}{20} & \multicolumn{2}{|r|}{30} & \multicolumn{2}{|r|}{40} & \multicolumn{2}{|r|}{50} & \multicolumn{2}{|r|}{60} \\
\hline \multirow{6}{*}{$\begin{array}{l}\text { 歯 } \\
\text { 肉 } \\
\text { 縁 } \\
\text { 形 } \\
\text { 態 }\end{array}$} & 近 & $\frown$ & 31 & $(51.7)$ & 30 & $(47.6)$ & 39 & $(83.0)$ & 37 & $(84.1)$ & 21 & $(65.6)$ & 7 & (53.8) \\
\hline & 心 & $\smile$ & 15 & $(25.0)$ & 11 & (17.5) & 2 & $(4.3)$ & 1 & $(2.3)$ & 5 & (15.6) & 2 & (15.4) \\
\hline & 側 & - & 14 & $(23.3)$ & 22 & $(34.9)$ & 6 & (12.8) & 6 & (13.6) & 6 & (18.8) & 4 & $(30.8)$ \\
\hline & 遠 & $\frown$ & 47 & $(78.3)$ & 24 & $(38.1)$ & 40 & (85.1) & 41 & $(93.2)$ & 25 & $(78.1)$ & 10 & $(76.9)$ \\
\hline & 心 & $\smile$ & 3 & $(5.0)$ & 14 & $(22.2)$ & 4 & $(8.5)$ & 1 & (2.3) & 3 & $(9.4)$ & 1 & $(7.8)$ \\
\hline & 側 & - & 10 & $(16.7)$ & 25 & $(39.7)$ & 3 & $(6.4)$ & 2 & $(4.5)$ & 4 & (12.5) & 2 & (15.3) \\
\hline 最 & 近 & 心 & 5 & $(8.3)$ & 5 & $(7.9)$ & 8 & $(17.0)$ & 10 & $(22.7)$ & 7 & (21.9) & 1 & $(7.8)$ \\
\hline 深 & 正 & 中 & 35 & $(58.3)$ & 44 & (69.8) & 37 & $(78.7)$ & 25 & $(56.8)$ & 22 & $(68.8)$ & 9 & $(69.2)$ \\
\hline 部 & 遠 & 心 & 20 & $(33.3)$ & 14 & $(22.2)$ & 2 & $(4.3)$ & 9 & $(20.5)$ & 3 & $(9.4)$ & 3 & $(23.1)$ \\
\hline 位 & 平上 & & & $.05 \mathrm{~mm}$ & & $07 \mathrm{~mm}$ & & $.05 \mathrm{~mm}$ & +0 & $.00 \mathrm{~mm}$ & +0 & $.05 \mathrm{~mm}$ & & $05 \mathrm{~mm}$ \\
\hline
\end{tabular}


表 13 歯肉縁形態の分類表

우 $\underline{2}$ （）内は\%を示し，十は最深部位の近心寄り，一は最深部位の遠心寄り

\begin{tabular}{|c|c|c|c|c|c|c|c|c|c|c|c|c|c|c|}
\hline \multicolumn{3}{|c|}{ 年 齢 } & \multicolumn{2}{|r|}{10} & \multicolumn{2}{|r|}{20} & \multicolumn{2}{|r|}{30} & \multicolumn{2}{|r|}{40} & \multicolumn{2}{|r|}{50} & \multicolumn{2}{|r|}{60} \\
\hline \multirow{6}{*}{$\begin{array}{l}\text { 歯 } \\
\text { 肉 } \\
\text { 縁 } \\
\text { 形 } \\
\text { 態 }\end{array}$} & 近 & $\frown$ & 33 & $(62.3)$ & 39 & $(58.2)$ & 44 & $(72.1)$ & 46 & $(95.8)$ & 33 & $(84.6)$ & 8 & $(100.0)$ \\
\hline & 心 & $\smile$ & 6 & (11.3) & 1 & $(1.5)$ & 4 & $(6.6)$ & 0 & $(0.0)$ & 4 & (10.3) & 0 & $(0.0)$ \\
\hline & 側 & - & 14 & $(26.4)$ & 27 & $(40.3)$ & 13 & (21.3) & 2 & $(4.2)$ & 2 & $(5.1)$ & 0 & $(0.0)$ \\
\hline & 遠 & $\frown$ & 33 & $(62.3)$ & 41 & $(61.2)$ & 50 & $(82.0)$ & 43 & $(89.6)$ & 36 & (92.3) & 8 & $(100.0)$ \\
\hline & 心 & $\smile$ & 14 & $(26.4)$ & 9 & $(13.4)$ & 3 & $(4.9)$ & 1 & $(2.1)$ & 0 & $(0.0)$ & 0 & $(0.0)$ \\
\hline & 側 & - & 6 & (11.3) & 17 & $(25.4)$ & 8 & $(13.1)$ & 4 & $(8.3)$ & 3 & $(7.7)$ & 0 & $(0.0)$ \\
\hline 最 & 近 & 心 & 10 & (18.9) & 17 & $(25.4)$ & 10 & (16.4) & 7 & (14.6) & 1 & $(2.7)$ & 1 & (12.5) \\
\hline 深 & 正 & 中 & 33 & $(62.2)$ & 41 & $(61.2)$ & 44 & $(72.1)$ & 30 & $(62.5)$ & 37 & $(94.9)$ & 4 & $(50.0)$ \\
\hline 部 & 遠 & 心 & 10 & (18.9) & 9 & (13.4) & 7 & (11.5) & 11 & $(22.9)$ & 1 & $(2.7)$ & 3 & $(37.5)$ \\
\hline 位 & 平土 & & & $63 \mathrm{~mm}$ & & $04 \mathrm{~mm}$ & & $01 \mathrm{~mm}$ & & $05 \mathrm{~mm}$ & & $\mathrm{~mm}$ & & $20 \mathrm{~mm}$ \\
\hline
\end{tabular}

表 14 歯肉縁形態の分類表

今 3 （）内は\%を示し，十は最深部位の近心寄り，一は最深部位の遠心寄り

\begin{tabular}{|c|c|c|c|c|c|c|c|c|c|c|c|c|c|c|}
\hline \multicolumn{3}{|c|}{ 年 齢 } & \multicolumn{2}{|r|}{10} & \multicolumn{2}{|r|}{20} & \multicolumn{2}{|r|}{30} & \multicolumn{2}{|r|}{40} & \multicolumn{2}{|r|}{50} & \multicolumn{2}{|r|}{60} \\
\hline \multirow{6}{*}{$\begin{array}{l}\text { 歯 } \\
\text { 肉 } \\
\text { 縁 } \\
\text { 形 } \\
\text { 態 }\end{array}$} & 近 & $\frown$ & 55 & (94.8) & 51 & $(79.7)$ & 40 & $(90.9)$ & 37 & $(97.4)$ & 27 & $(65.9)$ & 15 & $(93.8)$ \\
\hline & 心 & $\smile$ & 0 & $(0.0)$ & 0 & $(0.0)$ & 0 & $(0.0)$ & 1 & $(2.6)$ & 4 & $(9.8)$ & 0 & $(0.0)$ \\
\hline & 側 & - & 3 & $(5.2)$ & 13 & $(20.3)$ & 4 & $(9.1)$ & 0 & $(0.0)$ & 10 & $(24.4)$ & 1 & (6.3) \\
\hline & 遠 & $\frown$ & 1 & $(1.7)$ & 10 & (15.6) & 13 & $(29.5)$ & 17 & $(44.7)$ & 12 & $(29.3)$ & 7 & $(43.8)$ \\
\hline & 心 & $\smile$ & 42 & $(72.4)$ & 38 & $(59.4)$ & 15 & (34.1) & 12 & $(31.6)$ & 16 & $(39.0)$ & 2 & (12.5) \\
\hline & 側 & - & 15 & $(25.9)$ & 16 & $(25.0)$ & 16 & $(36.4)$ & 9 & $(23.7)$ & 13 & $(31.7)$ & 7 & $(43.8)$ \\
\hline 最 & 近 & 心 & 25 & $(43.1)$ & 9 & (14.1) & 10 & $(22.7)$ & 6 & (15.8) & 18 & $(43.9)$ & 9 & $(56.3)$ \\
\hline 深 & 正 & 中 & 27 & $(46.6)$ & 49 & $(76.6)$ & 32 & $(72.7)$ & 31 & $(81.5)$ & 22 & $(53.7)$ & 7 & $(43.8)$ \\
\hline 部 & 遠 & 心 & 6 & (10.3) & 6 & $(9.4)$ & 2 & $(4.5)$ & 1 & $(2.6)$ & 1 & $(2.4)$ & 0 & $(0.0)$ \\
\hline 位 & 平士 & & & $18 \mathrm{~mm}$ & & $02 \mathrm{~mm}$ & & $7 \mathrm{~mm}$ & & $08 \mathrm{~mm}$ & & $17 \mathrm{~mm}$ & $+c$ & $21 \mathrm{~mm}$ \\
\hline
\end{tabular}

表 15 歯肉縁形態の分類表

우 3 （）内は\%を示し，十は最深部位の近心寄り，一は最深部位の遠心寄り

\begin{tabular}{|c|c|c|c|c|c|c|c|c|c|c|c|c|c|c|}
\hline \multicolumn{3}{|c|}{ 年 齢 } & \multicolumn{2}{|r|}{10} & \multicolumn{2}{|r|}{20} & & 30 & \multicolumn{2}{|r|}{40} & \multicolumn{2}{|r|}{50} & \multicolumn{2}{|r|}{60} \\
\hline \multirow{6}{*}{$\begin{array}{l}\text { 歯 } \\
\text { 肉 } \\
\text { 緣 } \\
\text { 形 } \\
\text { 態 }\end{array}$} & 近 & $\frown$ & 49 & $(87.5)$ & 60 & (83.3) & 52 & $(78.8)$ & 47 & $(90.4)$ & 30 & $(71.4)$ & 6 & $(75.0)$ \\
\hline & 心 & $\smile$ & 3 & $(5.4)$ & 0 & $(0.0)$ & 1 & $(1.5)$ & 3 & $(5.8)$ & 0 & $(0.0)$ & 0 & $(0.0)$ \\
\hline & 側 & - & 4 & $(7.1)$ & 12 & $(16.7)$ & 13 & $(19.7)$ & 2 & $(3.8)$ & 12 & $(28.6)$ & 2 & $(25.0)$ \\
\hline & 遠 & $\frown$ & 10 & $(17.9)$ & 10 & (13.9) & 11 & $(16.7)$ & 5 & $(9.6)$ & 17 & $(40.5)$ & 8 & $(100.0)$ \\
\hline & 心 & $\smile$ & 32 & $(57.1)$ & 37 & $(51.4)$ & 34 & $(51.5)$ & 27 & (51.9) & 11 & $(26.2)$ & 0 & $(0.0)$ \\
\hline & 側 & - & 14 & $(25.0)$ & 25 & $(34.7)$ & 21 & (31.8) & 20 & $(38.5)$ & 14 & (33.3) & 0 & $(0.0)$ \\
\hline 最 & 近 & 心 & 39 & $(69.6)$ & 34 & $(47.2)$ & 32 & $(48.5)$ & 22 & $(42.3)$ & 22 & $(52.4)$ & 0 & $(0.0)$ \\
\hline 媣 & 正 & 中 & 17 & $(30.4)$ & 36 & $(50.0)$ & 33 & $(50.0)$ & 30 & $(57.7)$ & 20 & $(47.6)$ & 8 & $(100.0)$ \\
\hline 部 & 遠 & 心 & 0 & $(0.0)$ & 2 & $(2.8)$ & 1 & $(1.5)$ & 0 & $(0.0)$ & 0 & $(0.0)$ & 0 & $(0.0)$ \\
\hline 位 & 平土 & & & $32 \mathrm{~mm}$ & & $19 \mathrm{~mm}$ & & $19 \mathrm{~mm}$ & & $18 \mathrm{~mm}$ & & $19 \mathrm{~mm}$ & & $00 \mathrm{~mm}$ \\
\hline
\end{tabular}


側は男性同様，凹型が $80 \%$ 以上で凸型が非常に 少ない。最深部位についても，10 歳代では遠心寄 りと正中線上がだいたい同数值であるが，20，30， 40 歳代では遠心寄りで，50 歳代，60 歳代になる と再び正中線上が多くなつている。

ii）杰について（表 12，13）

男性近心側は1に比べ，ばらつきが多く，だい たい凹型が 過半数を占めているが，20 歳代は 直 線型が多くなつているのが目だつ。1と比べて凸 型が 10 歳, 20 歳代で $20 \%$ 強となり, 萠出期の歯 肉縁の不安定を示している。遠心側は 20 歳代を 除き 80 \% 前後が凹型を示すが， 20 歳代の 変化は 強い。最深部位については $60 \%$ 以上が正中線上 にあるもので，近心寄りは 30 歳以上に $20 \%$ 前後 あり，遠心寄りは 10 歳，20歳の若年者に多く見 られる。

女性については近遠心とも凹型が $60 \%$ 以上を 占め, 男性程のばらつきが少なく, 最深部位も正 中線上が $60 \%$ 以上を各年代とも示している。

iii）亘について（表 14，15）

男女とも, 近心側は凹型が $70 \%$ 以上で凸型は非 常に少ない。3の特異性は遠心側に強く現われ，男 性では 10 歳代，20歳代 は 凸型が $60 \%$ 以上を占 め, 30 歳代以後は凹型，凸型，直線型に等分に分 布している。女性では 40 歳代まで約 $50 \%$ が凸型 を示し，50歳以上になると型が多くなる傾向を 示し，他の歯種では見られなかつた形状が出現し ている。最深部位について，男性は 50 歳頃まで は正中線上が多くなるが，女性では全年齢におい て正中線上と近心寄りが等分化し，遠心寄りのも のは数例しか見らけられなかつた。

1， 2 に掞いては凹型で，最深部位も正中線か 遠心寄りが多く見うけられた歯肉縁形態が、正の 遠心部だけは全く正反対となり，最深部位も正中 軸から近心寄りにあつた。このような形態は $\underline{3} の$ 植立状態, および歯冠形態の特異性によつて発現 したものと考えられよう。

\section{IV 考 察}

1952 年 Swissedent Foundation によつて補緅物
の Dentogenics が提唱され, 義歯に性差, 性格, 年 齢による特長を与えて自然観を獲得することの重 要性が強調された。いわゆる，S.P.A.(Sex, Personality, Age) 要素がこれである。彼らは義歯に これらの要素を表現することにより，機能的にも 形態的にも調和がとれた義歯ができあがると言つ ている。

そのご，歯牙と Dentogenics に関する報告はあ いついで発表され，1955年 Frush, Fisher らに よる一連の論文 ${ }^{11)-16)}$ がある。日本においても， 同じ目的のために饗庭, 羽賀らは排列, 歯牙色調 等の報告 ${ }^{17)-26)}$ を行なつている。

歯肉に関する報告においては大部分が病理組織 学的, 解剖学的な研究 ${ }^{2728)}$ が行なわれ, 牧 ${ }^{29}$ は歯 肉の厚さについて計測している。また，末高 ${ }^{301}$ は 生体歯肉の形態の加令的変化について臨床的に観 察し，その歯肉の彎曲度を分類し統計的観察を行 なつている。しかし，明確な基準によつて詳細な 観察，計測を行ない，Dentogenics のための個々 の資料を集積する点では，まだ多くの分野が残さ れている。

これは対象自体が歯牙萠出より歯肉の退縮へ移 行する過程において，歯種，歯型，年齢，性差が あり，変異も強いので量的取扱いが比較的困難な ことによるものであろう。

本研究は Dentogenics の一部門として, 臨床歯 冠の増令的変化の量的表現を目的としてなされた ものである。そして，まず解剖的歯冠形態を調査 して, 計測值に上る歯型の分類を行なつたのち, 正 常歯列で健康歯肉縁を有する資料を選んで, 歯種, 年齢, 性差の関係をつとめて推計学的に検討し， 補緅臨床，特に全部義歯床製作時，歯肉縁部の形 成に際して具体的な形成基準が得られるように努 めた。以下，各項について考察を進める。

\section{研究方法について}

歯牙の萠出，歯肉の 退縮に 伴なつて 臨床的歯 冠形態も変化する。その変化を量的に表現するた めには，咬合平面等を基準平面として数量的に処 理するか，歯牙自体に基準を求める方法とがあ る。本研究では後者の立場を採り，その基準を歯 
冠軸に求めた。この場合, 抜去歯牙の計測と異な り, 天然歯列弓における歯牙の植立状態の検討は 歯根抢よび歯冠の一部が歯周組織に覆われている ために, 藤田ら ${ }^{3132)}$ の解剖学的計測法の適用はで きない。なお，天然歯列弓における歯牙は唇舌的 傾斜角度, 近遠心的傾斜角度および捻転角度の 3 者によつて表わされるが，著者は歯冠の基準軸お よび基準平面を富士川 ${ }^{5)}$ の歯冠軸決定法を採用し た。

また, 計測は 1 歯ごとに撮影した歯冠の唇面観 の規格写真上で行なつた。この場合, 使用した写 真撮影装置は飛奈の研究に使用したものである。 そのさい，歯冠軸および基準平面の決定に 際し て，必ずしも幾何学的にこれを決定することはむ ずかしかつたが，それは当該歯を直接観察して妥 当な線を求めて補うこ上とした。

\section{測定誤差について}

この測定方法によると, 次の 2 種類の原因によ つて誤差を生ずる可能性がある。

1）歯牙の基準面および歯冠軸判定の誤差

歯牙の形態は種々変化に富み, ことに咬耗, 磨 耗，萠出不全等によつて，歯牙の基準面および歯 冠軸は著しく変化するので必ずしも正確な判定は できない。

歯の傾斜を測定する目的で富士川年は同一顎に ついて 20 回の測定を行ない，測定值より標準偏 差を求めた結果, 大部分が誤差 $1^{\circ}$ 以下であると 報告している。また，基準面および歯冠軸の判定 には歯頸線の位置を基準としているので, 判定に は萠出度の影響も多く受ける。抜去歯牙の歯頸線 上 $2 \mathrm{~mm}$ までワックスで覆つた模型上での測定誤 差は, 前歯部で測定值の最大值と 最小值の 差は $2^{\circ} \sim 3^{\circ}$ のひらきがあつたと報告している。

著者の場合, 歯牙唇面の計測が目的であつたか ら基準面およで歯冠軸の測定誤差が $3^{\circ}$ であると 仮定しても，その誤差が歯冠幅，歯冠長に及ぼす 影響は $1 \%$ 以下となり，計測に及ぼす誤差として 全く取り扱う必要を認めなかつた。

2）咬耗の補正に伴なう誤差

歯牙の咬耗は多かれ少なかれ全歯牙に認められ
る。計測資料はできるだけ咬耗の少ないものを選 んだが，計測にあたうて適正なる補正を行なわな ければならない。補正は歯牙形態, 特に切縁部拧 よび尖頭はその形態が種々さまざまであるので, 全歯牙について統一した数学的補正值線等で咬耗 を補正することは不可能であつた。

補正は菖蒲沢氏のエナメル質の厚さ, ならびに 咬耗に関する研究を参考とし，また，諸氏の解剖 学 ${ }^{33}{ }^{34)}$ より歯冠の概形を検討して, 適宜, 歯冠形 態を回復し補正した。切歯部では葛蒲沢氏によれ ば，切歯部切縁部のエナメル質の厚さが約 $1 \mathrm{~mm}$ 弱であるので, 象牙質の露出の有無, 程度を判定 するとともに，切縁部形態のうち近心偶角，遠心 偶角や隆線を参考とした。犬歯については尖頭の 咬耗が強く，大部分の歯牙は象牙質が露出してい るし，生た，尖頭形態が切歯部に比べ変化が強い ので，咬耗状態を参考にするとともに，近遠心切 縁形態，唇舌侧中央隆線形態を参考にして補正值 を算出した。

上記の補正が適正であるか否かについて誤差を 算出した。算出方法は全く咬耗の見られない歯牙 または口蓋側のみで，唇面切縁にまで咬耗が及ば ない抜去歯牙を無差別に取り出し，前述の計測方 法で規格写真を作製した。その写真上で歯冠長を 計測したのち，同一全歯牙を任意に切縁を削除し て咬耗歯を形成, 再び, 写真上で上記補正方法で 補正を行ない計測した。すなわち，咬耗のない歯 牙の歯冠長をXとし，補正後の歯冠長を $\mathrm{Y}$ とする 々，その誤差 $Z=Y-X$ となる。計測歯牙の選択 も無差別的に取り, また, 変量X, Y が正規分布 をするので誤差 $Z$ も正規分布をする。 $Z$ の母集団 について考えるとき母平均は 0 であり，「Zが母 平均 0 なる正規母集団である」と仮説して, 補正 の適正の有無を判定した。

各歯種別に $Z$ の平均值 $\bar{z}$, 不偏分散 $\mathrm{u}^{2}$ を算出し たのち，平均值の比較を $\mathrm{t}_{\mathrm{s}}=\mathrm{z}-\mathrm{m} / \frac{\mathrm{u}}{\sqrt{\mathrm{N}}}$ を用いて 推計をした。この場合 $\mathrm{m}=0$ である。その結果 1 については仮説を否定できなかつたが，， ついては $1 \%$ ，2％で否定された。すなわち，宸， 白の場合, 補正值は実測值より幾分長くなる傾向 
表 16 誤差の推計値表（計測值による推計値）

\begin{tabular}{c|c|c|c}
\hline & $\underline{1}$ & $\underline{2}$ & $\underline{3}$ \\
\hline $\mathrm{N}$ & 49 & 105 & 117 \\
$\overline{\mathrm{z}}$ & 0.04 & 0.22 & 0.22 \\
$\mathrm{u}^{2}$ & 0.446 & 0.471 & 1.018 \\
$\mathrm{ts}$ & 0.43 & 3.27 & 2.38 \\
$\mathrm{P}_{\mathrm{r}}(\mathrm{t})$ & $\mathrm{t}_{\mathrm{s}}>\mathrm{P}_{\mathrm{r}}(\mathrm{t}=0.7)$ & $\mathrm{t}_{\mathrm{s}}>\mathrm{P}_{\mathrm{r}}(\mathrm{t}=0.01)$ & $\mathrm{t}_{\mathrm{s}}>\mathrm{P}_{\mathrm{r}}(\mathrm{t}=0.02)$ \\
$1 \%$ 棄却限界 & $-1.77 \leqq \mathrm{z}_{0} \leqq 1.85$ & $-1.58 \leqq \mathrm{z}_{0} \leqq 2.02$ & $-2.42 \leqq \mathrm{z}_{0} \leqq 2.86$ \\
$5 \%$ 杗却限界 & $-1.32 \leqq \mathrm{z}_{0} \leqq 1.40$ & $-1.15 \leqq \mathrm{z}_{0} \leqq 1.59$ & $-1.78 \leqq \mathrm{z}_{0} \leqq 2.22$ \\
$1 \%$ 最高誤差率 & $4.5 \%$ & $6.1 \%$ & $8.0 \%$ \\
$5 \%$ 最高誤差率 & $3.4 \%$ & $5.0 \%$ & $6.1 \%$
\end{tabular}

があることが認められた。

上記の傾向についてさらに検討を加えた。すな わち，Zの存在範囲について $\mathrm{F}$ 分布表より $1 \%$, $5 \%$ の危険率のもとで棄却限界を求めた。

表 16 の棄却限界より, 最少歯冠長(実長の 4 倍 大） 1 を $41.0 \mathrm{~mm} ， \underline{2}$ を $33.0 \mathrm{~mm}$ ，色を 36.0 $\mathrm{mm}$ とすると, 最大誤差率を $1 \%$ 棄却限界の場合 にとれば， $4.5 \% ， 6.1 \% ， 8.0 \%$ となるが，この 誤差率が起こりうる可能性は非常に少ないことは 言うまでもない。全資料の約 $70 \%$ は最少歯冠長 を規準としても，誤差率は $1.7 \% ， 2.7 \% ， 3.4$ \%以下となるので，上記補正方法は適正であると 認めて以後の計測を行なつた。

\section{解剖学的歯冠形態について}

補緅ならびに解剖学教室所有の抜去歯牙 (1 219 歯， 는 277 歯， $3 ， 236$ 歯）の規格写真を 作製し，写真上で歯冠幅と歯冠長を計測した。資 料の各平均值は従来の報告 ${ }^{35)}{ }^{36)}$ と比較検討したが 差は少なく，正規母集団よりの無差別抽出による ものと考えた。

はじめ, 各抜去歯牙の歯冠幅, 歯冠長より求め た歯冠幅長示数は, その度数分布曲線が正規型を 示していたが，分散が大きく，はなはだ不揃いな 材料から統計したものであると予想された。そこ で, 試みに $5 \%$ 棄却限界を求めたところ, 限界外 にあるもの11〜15 例の多きにのぼり，標本その ものの母集団の純度を疑わせるものがあつた。そ こで, 著者は改めて歯冠形態の分類基準を定める ことを企図した。

歯の形態を左右する要因にはいろいろあろう が, 主として, 歯冠長, 歯冠幅との 2 変数によつて 大きく作用される。歯型についての 分類は 1914 年 Williams によつて前歯を各 3 型に分類してょ り，そのご，これが細分類されている。市川，渡 辺 ${ }^{37)}$ は歯型を長幅示数で分類し統計を行なつてい る。また，杉浦ら ${ }^{38)}$ は合成樹脂歯との比較におい て, 天然歯の幅長示数を用いているが, 著者は単 なる幅長示数の分散による資料の分類を避けて, 歯冠長, 歯冠幅それぞれの平均值の確率誤差によ る標本の分類を行なつた。そして長型, 正常型, 短型に 3 分類した。これによつて, 幅長示数の持 つ意義が実存の歯冠形態に，より具体的に結びつ けられたと考える。

\section{ベクトル表示法による各歯型の分布状態}

歯冠形態を数学的に表現するために, 平面上の ベクトルで型を表わすことができれば理解しやす い。すなわち, 一変数の標本を図示すれば直線上 の点として表わされるが，型の標本，いいかえれ ば 2 変数の標本は平面上のベクトルとして図示さ れる。

正常型, 長型, 短型に分類された各歯牙は, そ の歯冠幅, 歯冠長を直角座標上の $\mathrm{X}$ 軸, $\mathrm{Y}$ 軸に, それぞれベクトルで表示すれば，その複合ベクト ルはX軸となす角度と原点よりの距離で代表さ れ，各歯牙固有のべクトルを示すことになる。 一変数の正規母集団で母平均を示す点があつた ごとく，型を示す母集団ベクトルでも母平均べク トルがある。同様に, 一変数の棄却限界に相当す 
表 17 抜去歯牙: 正常型の幅長示数の推計值

\begin{tabular}{c|c|c|c}
\hline \hline & $\mathbf{1}$ & $\mathbf{2}$ & $\mathbf{3}$ \\
\hline$\overline{\mathrm{x}}$ & 140.47 & 144.45 & 144.02 \\
$\mathrm{u}^{2}$ & 20.75 & 45.70 & 42.71 \\
$99 \%$ - 信頼限界 & $141.72 \geqq \mathrm{~m} \geqq 139.47$ & $145.86 \geqq \mathrm{~m} \geqq 143.04$ & $145.43 \geqq \mathrm{~m} \geqq 142.62$ \\
$95 \%$-信頼限界 & $141.23 \geqq \mathrm{~m} \geqq 139.71$ & $145.52 \geqq \mathrm{~m} \geqq 143.38$ & $145.09 \geqq \mathrm{~m} \geqq 142.96$ \\
$1 \%$-棄却限界 & $152.40 \geqq \mathrm{X}_{0} \geqq 128.54$ & $162.15 \geqq \mathrm{X}_{0} \geqq 126.75$ & $161.14 \geqq \mathrm{X}_{0} \geqq 126.91$ \\
$5 \%$ 一棄却限界 & $149.51 \geqq \mathrm{X}_{0} \geqq 131.43$ & $157.86 \geqq \mathrm{X}_{0} \geqq 131.04$ & $156.99 \geqq \mathrm{X}^{0} \geqq 131.06$
\end{tabular}

る 2 変数べクトルの棄却限界は楕円面として表現 され，図示できる。

正常型の $5 \%$ 棄却楕円を求めると, 楕円の中心 は歯冠幅, 歯冠長の各度数分布の平均值となり, 楕円の長軸とX軸とのなす角 $\theta$, 楕円の長径, 短 径, 焦点距離を算出し楕円を図示した。例数が少 ない場合は棈円が相対的に大きくなるが, 全歯種 とも 100 例以上をもつて棄却楕円を作つたので， 相当の信頼性があると思われた。正常型の $5 \%$ 棄 却楕円外にある点の座標で示される心゙クトルは異 常べクトルであるとみなすことができる。異常で あるというのは測定のまちがいを発見するという 消極的なものでなく，むしろ正常型についての 5 \%菓却楕円を用いて, 長型, 短型, その他の型を 見いだすという積極的な応用に使用すべきもので ある。

楕円の中心と座標の原点を結ぶ直線を分割線と すると，楕円の周囲に散在している複合ベクトル は, 分割線の左上方が 短型, 右下方が長型であ る。分割線上にあり, 楕円の外にあるものは正常 型を相似的に拡大または縮小した別型で, ベクト ルの方向のみ正常(幅長示数が同数值)型と同じで あり，ベクトルの大きさという点が違つている。 この別型は正常型とは違つた母集団を持つと考え ることができる。

正常型の幅長示数の度数分布をとり, 分類前の 度数分布との比較を行なつた。不偏分散が分類す ることにより $1 / 4$ 〜 $1 / 3$ に減少した。また $5 \%$ の危 険率で棄却限界を求めたところ, 分類前において 限界外に相当数分散していた幅長示数は, 分類後 それぞれの母集団内におさまつた（表 17）。
正常型の歯冠幅長示数の度数分布曲線について 正規型に対する適合度の検定を行なつた。

$\chi^{2}$-分布表で自由度 $\mathrm{K}-3$ に対する $5 \%$ 值 $\chi_{0}{ }^{2}$ よ りも，各歯種の $\chi_{\mathrm{s}}{ }^{2}$ は小となり正規型と認めた。 しかし $\underline{2}$ の $\chi_{\mathrm{s}}{ }^{2}$ と $\chi_{0}$ の差は少なかつたが, 例数 を増加することにより，さらに適合度がよくなる と考えられる。

長型, 短型の度数分布曲線は正常型の平均值に 向つて片寄り正規型とみなされなかつた。そこで 各度数分布は Mean, Median, Mode 值より曲線 を描いた。

\section{臨床的歯冠形態について}

臨床的歯冠形態は年齢, 性差により歯肉の態度 が異なる。したがつて臨床的歯冠形態を検討する 場合には，その歯に固有の解剖的歯冠形態に関す る検討と歯肉に関する検討が同時に行なわれるべ きである。

計測は抜去歯牙同様, 規格写真上で行なつた。 写真撮影にあたり，歯冠軸決定による誤差を少な くするために正常歯列保有者の上顎前歯部模型を 1 歯ごとに分割し, 分割模型を製作した。分割に より，歯間乳頭の位置が不明瞭になるので，その 位置を模型上に記録することにより防いだ。

臨床的歯冠形態は歯肉によつて歯冠の一部が覆 われ, その程度が年齢とともにに変化するので, 抜 去歯牙の歯冠形態分類のように, 歯冠幅, 歯冠長 の平均值の確率誤差值で歯型を 3 分類することは 資料ならびに時間的にも不可能であり，また，不 正確となる。なぜならば，ある年齢における資料 についての臨床的歯冠形態を分類するためには, 抜去歯牙で行なつた分類方法と全く同じように行 
なわねばならない。また，資料が少なければ棄却 棈円は大きくなり不正確となるからである。

そこで，著者は解剖的歯冠の正常型の検討に際 して適用した棄却棈円を利用することに上り，臨 床的歯冠形態の分類を行なつた。

抜去歯牙に打ける正常型の存在範囲を $5 \%$ 㶳却 棈円として求めたが，この解剖的歯冠は臨床にお いては完全萠出した状態とみなすことができる。 本資料では，この時期がおおむね 50 歳にあつた。 そこで, 仮に 50 歳がこの完全萠出の 時期である とすれば, 30 歳の時の正常型の臨床歯冠は歯肉に よつて，どの程度覆われているかを逆に推計する ことにより, 30 歳の時の臨床歯冠の正常型の存在 範囲が棈円として求められる。すなわち, 直角座 標上で抜去歯牙における正常型の $5 \%$ 棄却楕円の 中心点が歯肉に覆われた長さだけ, 歯冠長のみが X軸に平行移動すればよいこととなる。そして, この楕円の中に入るものが正常型である。この場 合, 歯冠幅( Y 軸) は抜去歯牙と臨床歯冠とでは, その平均值に有意差なしとした。

このようにすれば，資料の分類に際して時間的 にも正確度のうえからも，より理論的であると思 う。

\section{歯冠幅長示数の増令的変化について}

正常歯冠形態群について 1 歳ごとの臨床歯冠幅 長示数の平均值を求め，これを図示したが，比較 菂, 示数の変化の激しい10 15 歳では小数例を もつて平均值を算出し，歯冠幅長示数一年齢曲線 を描くことは不可能であつた。そこで，歯牙の萠 出期を参考 ${ }^{39)}$ 40) として 15 歳以上の示数曲線との 移行を考慮して曲線化した。このことは歯間乳頭 一年齢曲線についても同様である。

幅長示数一年齢曲線はだいたい 3 分類された。 すなわち，直線的に示数の急上昇を示す時期（萠 出期）と, 示数の平行した状態が続き, 萠出の停 止した時期 (停止期), 停止期より再び示数の上 昇を示す，いわゆる歯肉の退縮が始まる時期（退 縮期）に分けることができる。

このようにして，本研究資料における増令的な

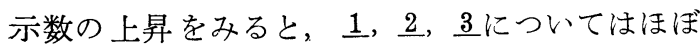

同じ傾向があり，女性の萠出時期は男性のそれに 比ベ早く, この時期の示数曲線は男性より常に高 かつた。これ满出時期がほぼ等しい白の場合で も認められた。つまり，20歳までは女性の萠出 度が男性よりいくぶん高いことを示している。し かし， 20 歳以後では女性の上昇曲線はゆるやか になるのに対して，男性は明らかな彎曲がなく上 昇を続けた。男女両曲線の交差する時期は全歯種 とも $20 \sim 30$ 歳にある。この交差点を越えると, 男 性の萠出は女性より高くなるが, 両曲線とも若年 期における急激なる上昇は横ばい状態に入つて, いわゆる停止期がくる。停止期の期間は各歯種に より異なるが，一般に女性に明膫に，かつ比較的 長くあらわれる。

停止期以後, 再び示数曲線の上昇が始まり, 歯 肉の退縮が起き始めるが, 各歯種とも男性の退縮 曲線が強い。完全萠出は 60 歳前後で起こるが, そ の時期差は全歯種とも男性が 5 歳ほど早い時期に 来るようである。この完全萠出時期について，未 高 $^{301}$ は歯根露出の出現率を次のように報告してい る。すなわち, 40 年層では1， 杰は 10 13.5\%, 负が $27 \%, 50$ 年層に達すると $1 ， \underline{2}$ が 23〜25\% 正が $39 \%$ となり，60 年層になると，その出現率 が前時期より $15 \%$ 前後下がる。そして, 女性で, は男性と同じ出現様式を示寸が，一般に低率で 50 年層でも $20 \%$ に達するものは吕の $25 \%$ のみで あるとのことである。また, 未高, 恩田 ${ }^{28)}$ は歯肉 縁と歯頸線の関係につき報告しているが，30 49 歳頃の歯根の露出は 1 が $7.1 \%, \quad 2$ が $26.3 \%$, 正が $58.8 \%$ で，50 歳以上では 1 が $38.5 \%$ ，杰が $58.3 \%$ ， 正で $81.3 \%$ あるると言つている。大西 ${ }^{41}$ 北村はレントゲン造影法による歯冠の萠出状態を 観察し，1の解剖歯冠長と臨床歯冠長の一致は露 出年齢 40 年前後であると報告している。本研究 結果をこれらの報告と比較すると, 完全萠出の時 期については各歯種とも多少のずれがあるが，こ れは研究の対象とした資料の相違によるものと考 える。すなわち, 著者は資料の蒐集にあたり, 比 較的歯根露出の少ないものを採り，高度に歯根露 出したものは歯周症の存在を疑つて除外したこと 
による。むしろ，逆に，末高の報告にもあるよう に，60 歳以上の歯根露出出現率が，むしろ低下す るということからみても，資料の採り方によつて は完全萠出がある程度変ることが予想される。

このような一連の変化曲線は 皮膚 ${ }^{22)}$ や生体反 応 ${ }^{43)}$ において記録される年齢的変化曲線と同じ傾 向であることは，歯牙の萠出と全身的な生体反応 との間に一連の関連性があることを思わせる。

表 18 臨床歯冠模型 : 萠出曲線の 3 分類

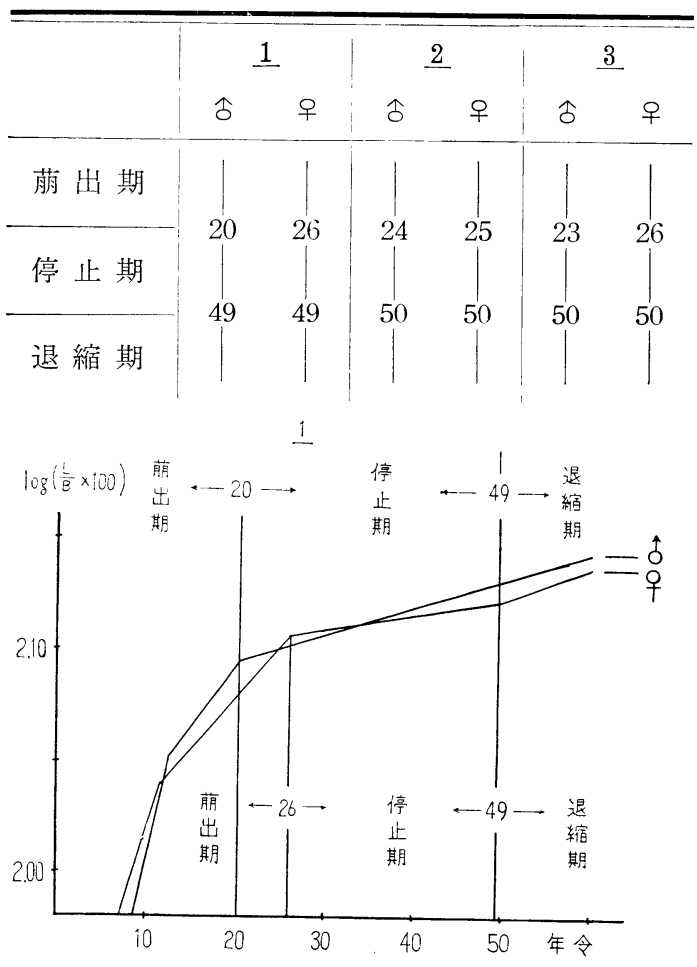

図 31 萠出曲線の 3 分類

\section{萠出曲線の 3 分類}

歯冠幅長示数の対数をとり, その増令的变化を グラフにすると（図 31), 上述した萠出期, 停止 期, 退縮期の 3 時期が明瞭に区分される。そして 表 18 に示すように, それぞれの時期に男女差が あることがわかる。

\section{歯間乳頭の増令的変化について}

歯間乳頭の位置を切縁(尖頭)線および歯肉の最 深点よりの距離で表現して, その変化を増令的に 検討した。
歯肉形態示数 $(\mathrm{a} / \mathrm{B} \times 100, \mathrm{~b} / \mathrm{B} \times 100)$ は切端か ら歯間乳頭頂までの距離と臨床歯冠長との差を示 数で表わしたものに相当する。したがつて,この示 数の堌減は歯間乳頭の退縮と歯肉の最深点, 寸な わち歯肉縁の後退とのずれを表わす。曲線の上昇 期はそれが急であるほど, 切縁からみて歯肉の後 退ないし歯牙の萠出が優位であることを意味し，

下降は歯肉の動きがある恒常状態に達したあとは 歯間乳頭の退縮が盛んであることを物語り，その ご，年齢軸に平行に近づくか，再び上昇を始めれ ば歯間乳頭の退縮よりも歯肉縁の後退（歯根の露 出)がまさつていると考えられる。すなわち, $\underline{3} の$ 男性において 50 歳頃よりいくぶん上昇し始める が,これは歯根部の露出が加わるためと思われる。 歯肉縁形態で, 20 歳代は凹型が全年齢における よりも少ない。それにかわつて, 直線型が多くなる のは歯肉形態示数の 20 歳代が最も高い值をとる 点を考えれば直線型が増加するものと思われる。

歯肉形態示数を歯種別に比較検討した（図 32, 33，34，35）。男性の近心側について，歯肉形態 示数は 3 萠出時期のおくれによる 17 歳までを 除き, 常に, $\underline{3}$ は高い示数值を示し， $2 ， \underline{1}$ の順と なる。 50 歳以後は 3 の歯根部露出に伴なら示数の 上昇を認め， $2 ， 1$ との差はさらに大きくなる。

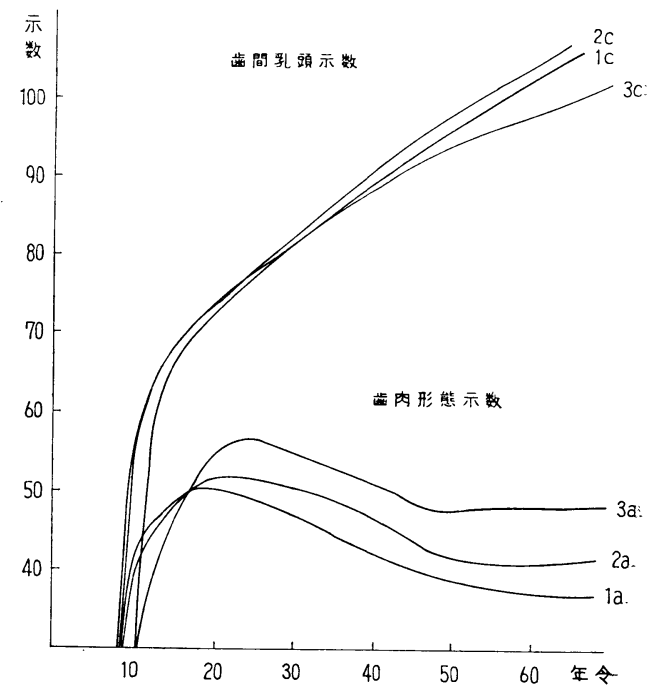

図 32 臨床歯冠 : 歯間乳頭の増令的変化 (部位差) 今近心側 


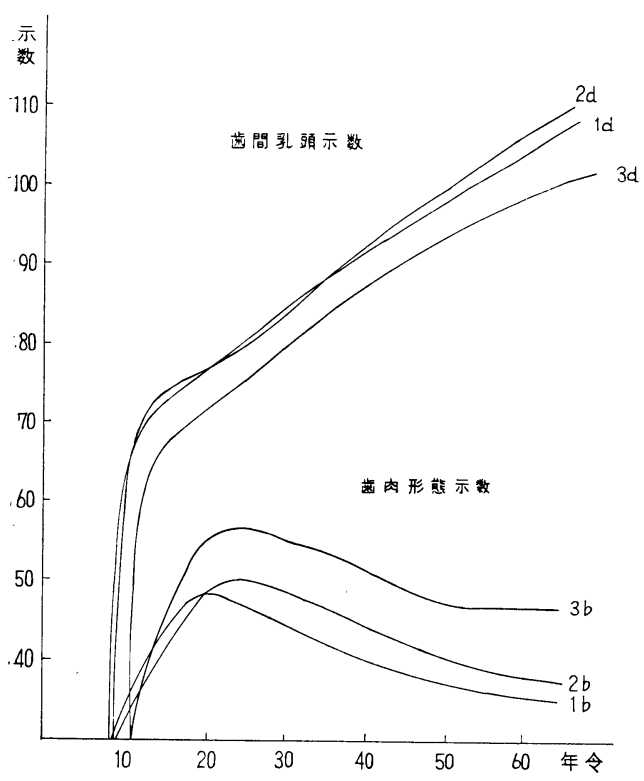

図 33 臨床歯冠 : 歯間乳頭の増令的変化 (部位差) 合遠心側

示数の最高值をとる時期は1が最も早く 18 歳 傾で，次いで 2021 歳， 3 は 24 歳頃となる。

遠心側については，示数曲線は近心側と同じ順 位となるが，最高值をとる時期は $2 ， \underline{3}$ が同時 となる。

女性については男性と同じく示数值の大きさの 順位に変化はないが，示数の最高值の時期は近遠 心側とも $1 ， \underline{3}, 2$ の順位となり，男性において の $1 ， \underline{2} ， \underline{3}$ と比べ $2 ， \underline{3}$ が逆になるが，その差

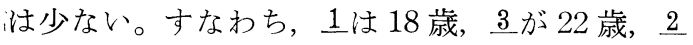
が 25 歳頃である。

\section{前歯部人工歯の位置的関係と臨床歯冠形態}

最後に, 本研究で得られた歯牙の萠出, 歯間乳 頭の高さ，歯肉縁最深部の位置の平均值を標準型 歯列模型図上に移して，その増令的変化を表現し てみよう。

本学補緅学教室では学生実習に人工歯排列基準 法 ${ }^{44)}$ として咬合平面を基準平面としている。す なわち，図 36 に示すごとく， 1 は咬合平面より $.2 \mathrm{~mm}, \underline{2}$ は $1 \mathrm{~mm}, \underline{3}$ は $2 \mathrm{~mm}$ 下がつた状態で ·排列をし，近遠心的傾斜角は富士川 ${ }^{5)}$ の歯冠軸測 定值の平均值をもつて代表とした。また，左右の

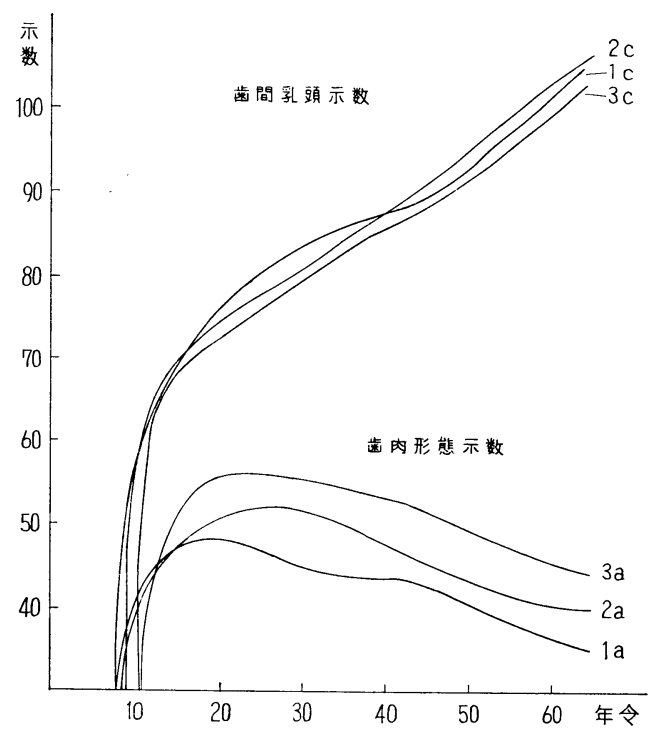

図 34 臨床歯冠 : 歯間乳頭の増令的変化 (部位差) 우近心側

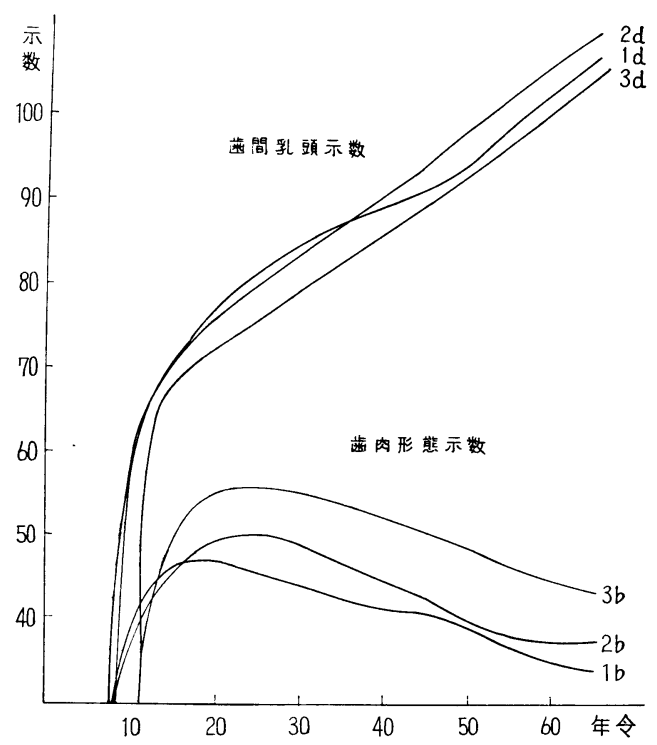

図 35 臨床歯冠 : 歯間乳頭の増令的変化 (部位差) 우遠心側

歯牙排列状態は対称形として図示した。

富士川の臨床歯冠の歯冠軸測定値は近遠心傾斜 角1が $2^{\circ} 82^{\prime} ， \underline{2}$ は $5^{\circ} 25^{\prime} ， \underline{3}$ は $7^{\circ} 65^{\prime}$ となつて いる。

すなわち, 各歯形図上に歯冠軸を基本線として 


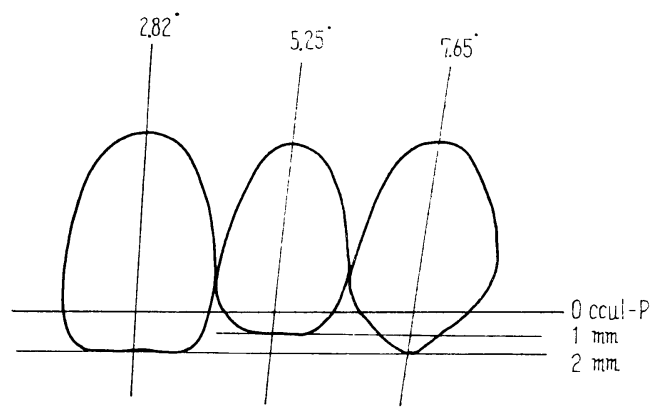

図 36 前歯排列基準と標準型歯列模型図

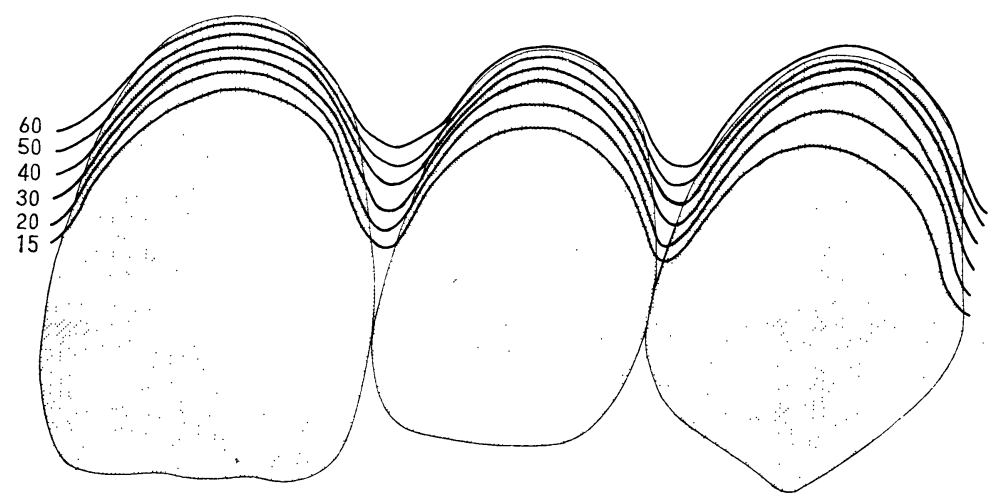

図 37 増令的にみた臨床的歯冠形態

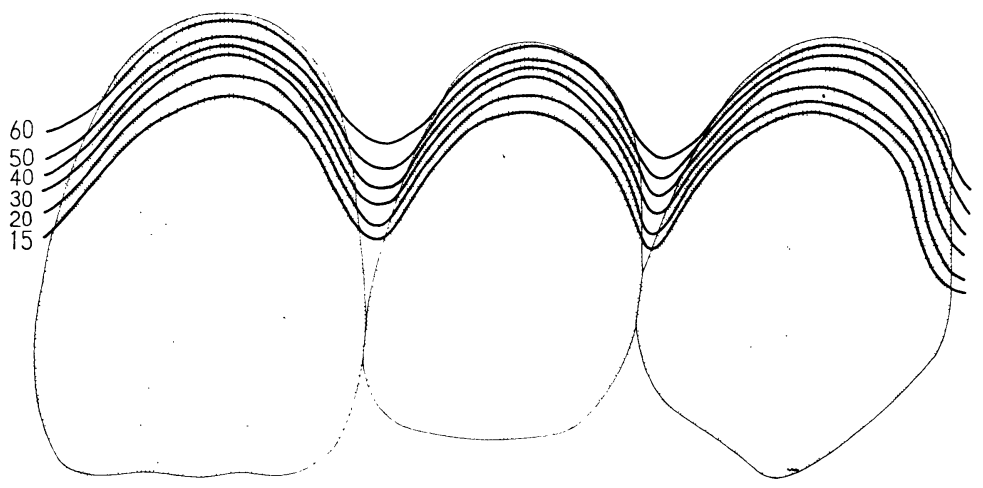

図 38 우 増令的にみた臨床的歯冠形態

年齢ごとの歯冠幅長示数，近遠心歯間乳頭示数 (歯肉形態示数), 歯肉縁の形態的変化, 最深部位 を記入し，各点を雲形定規で連权て曲線化した。 隣在歯間の数值の開きはその中間值をもつて代表 とした（図 37，38）。

年代の推移で 10 歳は萠出期にあたり, 非常に歯 肉縁が不安定な状態であり, 示数のばらつきも激
しいので 15 歳をもつて 10 代の代表とした。切端 側(尖頭)より 15 歳, 20 歳, 30 歳, 40 歳, 50 歳, 60 歳之なつている。

\section{V. 結 論}

1）臨床的歯冠形態の数量的表現を目的とし て，まず，解剖的歯冠形態を調查して計測值によ る歯型の分類を行なつたのち臨床歯冠形態を調査 し, 年齢, 性別, 歯種との関係を検討した。

2）歯冠形態の分類は正常型, 長型, 短型の 3 型に分類した。その分類規準 は歯冠長，歯冠幅それぞれの 平均值の確率誤差値を使用し た。

3）歯冠形態を左右する歯 冠長，歯冠幅をべクトルとし て表現を行ない，抜去歯牙の うち正常型について $5 \%$ 棄却 棈円を求め, その存在範囲を 棈円内に求めた。楕円の中心 は歯冠幅, 歯冠長の各平均值 を結ぶ点にあり，楕円の長 軸とX軸とのなす角 $\theta$ は 1 は $32^{\circ} 34^{\prime}, \underline{2}$ は $13^{\circ} 3^{\prime}, \underline{3}$ は $14^{\circ} 32^{\prime}$ となつた。

4) 正常型の歯冠幅長示数 の度数分布は正規型を示し た。長型, 短型の示数の度数 分布は正常型の平均値に向つ て片寄り，正規型とはみなさ れなかつた。

5）臨床歯冠資料の分類は 解剖的歯冠の正常型の $5 \%$ 棄却棈円を利用するこ とにより，各年齢階級に応ずる臨床的歯冠形態を 推定した。

6) 比較的臨床歯冠長の変化の少ない時期（30 〜 49 歳)について, 正常型群の歯冠幅長示数の左 右差を検討したが有意差は認められなかつた。

7）歯冠幅長示数の増令的変化曲線はだいたい 
曲線の傾向から 3 分類される。直線的に示数の急 上昇を示寸時期（萠出期）と示数の平行した状態 が続き，萠出の停止した時期(停止期)，停止期よ り再び示数の上昇を示す(退縮期)時期に分けられ た。

8）女性の萠出時期は男性のそれより早く，同 じく示数曲線は同時期において男性より常に高か つた。20歳以後では女性の上昇曲線 はゆるやか になるが，男性は上昇を続け，男女の交差する時 期は全歯種とも20３0 歳にある。

9）停止期は一般に女性に明瞭，かつ，比較的 長くあらわれる。

10）退縮曲線は各歯種とも男性が強い。完全萠 出は 50〜 60 歳で起こるが, その時期差は全歯種と も男性が 5 歳ほど早くなる。

11）歯間乳頭示数一年齢曲線は全般的に臨床歯 冠示数一年齢曲線と同じである。しかし，停止期 に相当するものが歯間乳頭示数曲線には明瞭に表 われなかつた。年齢, 性別に関係なく, 常に遠心 乳頭示数は近心のそれより高い值を示した。

12）歯肉縁示数はその最高値をとる時期は男性 で1が最も早く, 18 歳, 次いで 2 の 21 歳, 3 は 24 歳頃となる。女性では最高值を示す時期は $1, \underline{3}$, 2順位となり男性と異なる。

13）歯肉縁形態で1 120 歳代を除き, 凹型が 80 \%以上を占めているが，20歳代は直線型が多くな つている。杰の男性は1に比べ，ばらつきが多く， だいたい凹型が過半数を占めているが, 20 歳代は 直線型が目だつ。正は男女とも近心側は凹型が 70 \%以上であるが，遠心側に特異性が強く現われ凸 型が多くなつている。

14）最深部位は1，2においては正中線か，遠 心寄りが多く見うけられた歯肉縁形態が，白は正 中線上から近心寄りになつて, 反対の歯肉縁形態 を示した。

稿を終るに臨み, 終始御想篤な御指導と御校閲を賜り ました林教授に深甚なる謝意を表し，あわせて本研究に 御協力下さいました補释学教室員諸兄に深謝致します。

\section{文献}

1) Williams, J. L. : The esthetic and anatomical basis of dental prosthesis, D. C., $53: 1-26$, 1911.

2) Stein, M. R. : Williams' classification of anterior tooth forms, J. A. D. A., 23 : 1512-1518, 1936.

3) Wright, W. H. : Selection and arrangement of artificial teeth for complete prosthetic dentures, J. A. D. A., $23: 2291-2307,1936$.

4) 飛奈達也：有髄橋脚歯としての上顎中切歯形態 の研究, 口病誌, $25: 308-327,1958$.

5) 富士川善彦：天然歯列弓における歯冠傾斜角度 及び捻転角度の研究，口病誌，25：475-494, 1958.

6) 菖蒲沢 : 藤田恒太郎 : 歯の解剖学, 東京, 京都, 1957. 金原出版, p. 16 より引用.

7) 北条六男: 咬耗の研究, 解剖学雑誌, $25: 210$, 1950.

8）津田稔：歯牙咬耗の年齢的変動，歯科医学，15： $126,1952$.

9）尾花甚一：歯牙咬合小面の傾斜角度について, 口病誌, $24:$ 40-59, 1957.

10）高橋晄正, 土肥一郎：医学及び生物学研究者の ための推計学入門, 東京, 1951. 医学書院.

11) Frush, J. P. and Fisher, R. D. : Introduction to dentogenic restoration, J. P. D., 5:586595, 1955.

12) Frush, J. P. and Fisher, R. D. : How dentogenic restorations interpret the sex factor, J. P. D., $6:$ : 160-172, 1956.

13) Frush, J. P. and Fisher, R. D. : How dentogenics interprets the personality factor, J. P. D., 6 : 441-449, 1956.

14) Frush, J. P. and Fisher, R. D. : The age factor in dentogenics, J. P. D., $7: 5-13,1957$.

15) Frush, J. P. and Fisher, R. D. : The dynesthetic interpretation of the dentogenic concept, J. P. D., $8: 558-581,1958$.

16) Young, H. A. : Denture esthetics, J. P. D., $6: 748-755,1956$.

17）饗庭格太郎，羽賀通夫，浮谷実，江崎梅太郎，橋 本脩: 前歯排列の研究 (第一報), 補綴誌, $2: 135$ 138, 1958.

18）饗庭格太郎，羽賀通夫，浮谷実，江崎梅太郎，橋 本脩: 前歯排列の研究 (第二報), 正常型群の歯冠 傾斜角度, 補綴誌, $2: 141-144,1958$.

19）饗庭格太郎, 羽賀通夫，浮谷実，江崎梅太郎，橋 本脩 : 前歯排列の研究 (第三報), 正常群の前歯歯 列彎曲, $2: 145-148,1958$.

20）羽賀通夫，浮谷実，高梨恒一，岩瀬朗，沼沢孝人， 腰原好: 義歯の自然観に関する研究 (第一報), 前 歯の歯間離開, 補綴誌, 4:95-99, 1960. 
21）羽賀通夫，浮谷実，高梨恒一，岩瀬朗，沼沢孝人， 腰原好：義歯の自然観に関する研究 (第二報), 上顎中切歯の排列, 補緅誌, 5 : 58-62, 1961.

22）羽賀通夫，浮谷実，高梨恒一，岩瀬朗，沼沢孝人， 腰原好：義歯の自然観に関する研究 (第三報), 前歯の重なり, 補綴誌, $6: 53-56,1962$.

23）羽賀通夫，浮谷実，高梨恒一，岩瀬朗，沼沢孝人, 腰原好： 義歯の自然観に関する研究 (第四報), 前歯の重なり (2), $6: 159-163,1962$.

24）芳賀忠夫, 安藤義昭 : 歯牙の色沢について, 口腔 科学会誌, $3: 208,1954$.

25）加藤一男 : 歯牙の色沢の 年齢的変化について, 医学と生物学, 39, 156, 1956.

26) 羽賀通夫, 浮谷実, 橋本脩: 歯牙の色について, 補緅誌, 2 : 137-140, 1958.

27) 宮崎吉夫, 石川梧朗, 秋吉正豊 : 口腔病理学 (最 新歯科学全書 4 巻), 東京, 1954. 永末書店.

28）末高武, 恩田千爾 : 歯龈縁の 局所解剖学的研究, 東歯大解剖学教室業績集, 3 輯, 1957.

29) 牧正臣：九州日本人に於ける歯肉厚径及び其の 部位的等差に就いて, 熊大医学部解剖学教室業績 32 号, 1955.

30）末高武：生体歯肉の形態学的研究, 特に加需的 変化について, 東歯大解剖学教室業績集, 3 輯, 1957.

31) 藤田恒太郎 : 歯の計測規準について, 人類学雑誌, $61: 1,1949$.

32) 緒方健二：歯軸に関する一検索, 歯科医学, 8, 1937.
33）藤田恒太郎： 歯の解剖学, 東京, 京都, 1957. 金原出版.

34) 上条雍彦: 日本人永久歯の解剖学（口腔解剖学 $\left.\mathrm{II}_{6}\right)$ ，東京, 1962 . 地人書館.

35）三谷春保, 竜田早苗, 桜井襄二：邦人成年男子同 一個体の上顎 6 前歯の 歯冠近遠心径に 関する 統 計的研究 (第 1 報, 計測值及び幅径比), 歯科医学, $16,58,1953$.

36) 中村俊一 : 前歯, 東京, 1960. 而至化学, p. 34 上 り引用.

37）市川, 渡辺 : 上条雍彦：日本人永久歯の解剖学, 東京, 1962 , 地人書館, p. 11, 24, 51 より引用.

38）杉浦英二, 佐久間弘毅, 根本一男, 北条尚 : 上顎 中切歯の唇面形態に関する研究, 第 1 報, 唇面外 形について, 口病誌, $26: 629-633,1959$.

39）奥家広一：永久歯萠出の時期及び順序に関する 研究, 歯科学雑誌, $17: 30,1950$.

40) 岡本清桜：永久歯萠出時期の変異統計学的研究, 歯科学報, $39: 2,1934$.

41）大西正男, 北村中也：レントゲン造影法による中 切歯萠出と臨床歯冠形成に関する 研究, 第 29 回 口病学会講演内容抄録, 1964 .

42）伊崎正勝：老人性皮虐変化，皮膚科最近の進歩 III 集, 429-445, 1960.

43）緒方知三郎, 尼子富士郎, 沖中重雄 : 老年病学, 1, 2, 3 巻, 東京, 京都, 1958. 金原出版.

44）中沢勇：全部床義歯学, 京都, 東京, 1960. 永末 書店. 